\title{
Targeting Cell Survival Proteins for Cancer Cell Death
}

\author{
Manoj K. Pandey ${ }^{1, *}$, Sahdeo Prasad ${ }^{2}$, Amit Kumar Tyagi ${ }^{2}$, Lokesh Deb ${ }^{2}$, Jiamin Huang ${ }^{2}$, \\ Deepkamal N. Karelia ${ }^{1}$, Shantu G. Amin ${ }^{1}$ and Bharat B. Aggarwal ${ }^{2}$
}

1 Department of Pharmacology, College of Medicine, Pennsylvania State University, 500 University Drive, Hershey, PA 17033, USA; dkarelia@hmc.psu.edu (D.N.K.); sga3@psu.edu (S.G.A.)

2 Department of Experimental Therapeutics, Cytokine Research Laboratory, The University of Texas MD Anderson Cancer Center, Houston, TX 77030, USA; sprasad@mdanderson.org (S.P.); amittyagiiitd@gmail.com (A.K.T.); lokeshdeb.ibsd@nic.in (L.D.); zshuangjiamin@126.com (J.H.); bbaggarwa@gmail.com (B.B.A.)

* Correspondence: mkp13@psu.edu; Tel.: +1-717-531-1450; Fax: +1-717-531-5013

Academic Editors: Ashkan Emadi and Dhimant Desai

Received: 3 December 2015; Accepted: 16 February 2016; Published: 25 February 2016

\begin{abstract}
Escaping from cell death is one of the adaptations that enable cancer cells to stave off anticancer therapies. The key players in avoiding apoptosis are collectively known as survival proteins. Survival proteins comprise the Bcl-2, inhibitor of apoptosis (IAP), and heat shock protein (HSP) families. The aberrant expression of these proteins is associated with a range of biological activities that promote cancer cell survival, proliferation, and resistance to therapy. Several therapeutic strategies that target survival proteins are based on mimicking $\mathrm{BH} 3$ domains or the IAP-binding motif or competing with ATP for the Hsp90 ATP-binding pocket. Alternative strategies, including use of nutraceuticals, transcriptional repression, and antisense oligonucleotides, provide options to target survival proteins. This review focuses on the role of survival proteins in chemoresistance and current therapeutic strategies in preclinical or clinical trials that target survival protein signaling pathways. Recent approaches to target survival proteins-including nutraceuticals, small-molecule inhibitors, peptides, and Bcl-2-specific mimetic are explored. Therapeutic inventions targeting survival proteins are promising strategies to inhibit cancer cell survival and chemoresistance. However, complete eradication of resistance is a distant dream. For a successful clinical outcome, pretreatment with novel survival protein inhibitors alone or in combination with conventional therapies holds great promise.
\end{abstract}

Keywords: apoptosis; survival proteins; chemotherapeutics; nutraceuticals; Bcl-2 family; surviving

\section{Introduction}

Homeostasis in multicellular organisms is tightly maintained by a process known as programmed cell death or apoptosis. The aberrant regulation of apoptosis is associated with tumorigenesis and, importantly, in the development of chemoresistance. Several proteins that have been linked with dysregulated programmed cell death are collectively called survival proteins. Bcl-2, inhibitor of apoptosis (IAP), and heat shock protein (HSP) are considered to be the main survival protein families (Figure 1). The survival proteins impede cell death thus provide targets for possible drug discovery and development. This review describes the role of survival proteins in chemoresistance and summarizes some of the more promising strategies/agents for the modulation of survival proteins in cancer therapy. 


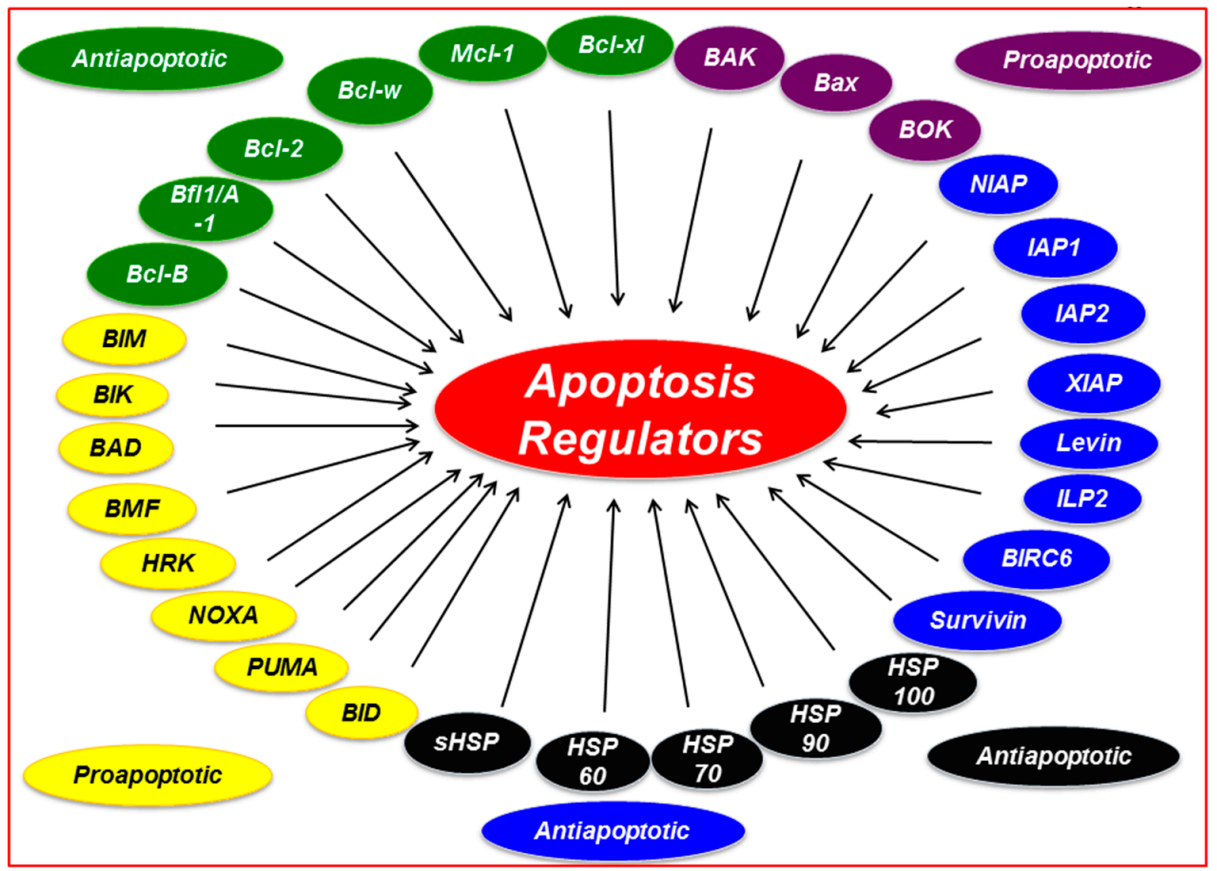

Figure 1. Survival family members associated with regulation of apoptosis. Abbreviations: Mcl-1, myeloid cell leukemia 1; Bcl-xL, B-cell lymphoma-extra-large; Bcl-2, B-cell CLL/lymphoma 2; Bcl-w, Bcl-2 like 2; BIM, Bcl-2 interacting protein; $\mathrm{BIK}, \mathrm{Bcl}-2$ interacting killer; $\mathrm{BAD}, \mathrm{Bcl}-2$ antagonist of cell death; BID, BH3 interacting domain death agonist; NOXA, Phorbol-12-myristate-13-acetate-induced protein 1; PUMA, p53 upregulated modulator of apoptosis; HRK, harakiri; BOK, Bcl-2 related ovarian killer; BAK, Bcl-2 antagonist killer1; BAX, Bcl-2 associated X protein; IAPs, Inhibitors of apoptosis; HSP, heat-shock protein.

\subsection{Bcl-2 Family}

In the past several decades, Bcl-2 family proteins have gained attention as apoptosis regulators. The Bcl-2 family consists of proteins that determine the fate of cells by promoting or inhibiting apoptosis. First identified in 1985 by Tsujimoto et al., to date, more than $25 \mathrm{Bcl}-2$ proteins have been characterized [1]. All Bcl-2 proteins are characterized by the presence of up to four Bcl-2 homology (BH) domains; these proteins can be divided into three subfamilies based on their structure and functions [2]. Group 1, the anti-apoptotic subfamily, contains the Bcl-2, Bcl-xL, Bcl-w, Mcl-1, Bfl1/A-1, and Bcl-B proteins, which suppress apoptosis and may contain all four $\mathrm{BH}$ domains. Group 2, a pro-apoptotic subfamily, contains the BAK, BAX, and BOK proteins, which are localized to the mitochondria, smooth endoplasmic reticulum, and perinuclear membranes and contain BH 1-3 domains. Group 3 consists of the pro-apoptotic BIM, BID, BIK, BAD, BMF, HRK, PUMA, and NOXA proteins, which contain only the $\mathrm{BH} 3$ domain and are known as "BH3-only" proteins [3,4].

In cancer cells, resistance to therapy evolves by various mechanisms. Among the most important of these mechanisms are the overexpression of anti-apoptotic genes and the downregulation or mutation of pro-apoptotic genes [5]. Extensive studies have established the role of the Bcl-2 family of pro-survival proteins in cell survival, proliferation, and chemoresistance in various tumors $[6,7]$. Based on their adverse role in patient outcomes, much attention has been given to this family in the search for new therapeutic regimens.

\subsubsection{Bcl-2}

The overexpression of the Bcl-2 protein is associated with malignancy and with poor prognosis in various cancers [8-14]. Several studies have shown that higher expression of Bcl-2 leads to resistance against radiation and chemotherapy $[12,15]$. How Bcl-2 is overexpressed in cancer cells 
is not fully understood; however, $\mathrm{Bcl}-2$ overexpression is correlated with chromosomal deletions leading to loss of Bcl-2-targeting miRNAs such as miR-195, miR-24-2, and miR-365-2 [16,17]; gene amplification [18]; and hypermethylation of the BCL2 gene [19]. Furthermore, several studies in the 1990s showed that the overexpression of pro-survival Bcl-2 proteins alone is not tumorigenic but that the concurrence of additional mutation(s), along with the overexpression of these proteins, is associated with chemoresistance in several malignancies [20-24].

\subsubsection{Bcl-xL}

$\mathrm{Bcl}-\mathrm{xL}$, an anti-apoptotic member of $\mathrm{Bcl}-2$ family, also has been investigated for its role in treatment resistance $[6,25]$. The overexpression of $\mathrm{Bcl}-\mathrm{xL}$ is associated with poor prognosis and chemoresistance in both hematological malignancies and solid tumors $[7,26,27]$.

\subsubsection{Mcl-1}

Mcl-1, which was first identified in human myeloid leukemia cell line ML-1, structurally resembles other anti-apoptotic Bcl-2 proteins [28]. However, Mcl-1 differs from other anti-apoptotic Bcl-2 proteins in its BH3 domain binding pattern, which involves the BH3 domain [29]. Several studies have suggested that Mcl-1 is required for embryonic development [30], survival of hematopoietic stem cells [31], and the survival of multiple cell lineages, including lymphocytes [32] and neurons [33]. As with other Bcl-2 family members, the overexpression of Mcl-1 has been reported in several malignancies [34,35], and its expression is often associated with treatment resistance, relapse [36], and poor survival outcomes [37,38]. In normal cells, the expression of Mcl-1 is regulated by both ubiquitin-dependent and ubiquitin-independent degradation $[34,39,40]$. To date, three E3 ubiquitin ligases have been identified that are involved in the regulation of Mcl-1 expression [40-42].

\subsubsection{Pro-Apoptotic Proteins}

As discussed above, chemoresistance not only may result from the overexpression of anti-apoptotic proteins but also from the inactivation of pro-apoptotic proteins. Along these lines, the inactivation of BAX is correlated with several malignancies [43,44]. Similarly, the inactivation of NOXA and PUMA are linked with tumorigenesis and treatment resistance $[45,46]$.

\subsection{IAP Family}

The IAP family proteins are another essential component in the survival of cancer cells. The overexpression of IAP proteins is associated with cancer cell survival, treatment resistance, and poor prognosis. Members of the IAP protein family were first discovered in the genetic screening of baculoviruses Orgyia pseudotsugata and Cydia pomonella [47-49]. Since then, eight IAP proteins have been identified in humans: NIAP, also called neuronal apoptosis inhibitory protein or BIRC1; c-IAP1, also called cellular IAP1 or BIRC2; c-IAP2, also called cellular IAP2 or BIRC3; XIAP, also called X chromosome-linked IAP or BIRC4; survivin, also called BIRC5; BIRC6, also called ubiquitin-conjugating BIR domain enzyme apollon; livin, also called melanoma IAP, ML-IAP, or BIRC7; and ILP2, also called IAP-like protein 2 or BIRC8 $[47,50]$.

The IAP family members control apoptosis through several mechanisms. The best understood of these mechanisms is caspase inhibition; others include the regulation of cell division, cell cycle progression, and signaling pathways. For example, XIAP and NAIP form a complex with the TAK1 kinase and its cofactor, TAB1, which leads to activation of c-Jun- $\mathrm{NH}_{2}$-terminal kinase 1 [51]. Furthermore, XIAP facilitates NF- $\mathrm{kB}$ activation, which contributes to tumorigenesis [52,53].

All IAP proteins contain the unique baculoviral IAP repeat (BIR) domain. Some IAP proteins (c-IAP1, c-IAP2, XIAP, and livin) also contain a carboxy-terminal RING domain. IAP proteins containing a RING domain work as E3 ubiquitin ligases and play important roles in cell survival and signaling pathways [54,55]. Based on the presence of the BIR and RING domains, this family is subdivided into three classes [56]. 


\subsubsection{Class 1 IAPs}

XIAP, cIAP1, cIAP2, ILP-2, and livin constitute the class 1 IAPs. These proteins contain homologous BIR domains and a RING finger motif. XIAP was first discovered, and among the members it is the best characterized [57]. It has three BIR and one RING finger domain. It has been shown that XIAP inhibits caspases 3, 7, and 9, but not caspase 8 [58,59]. cIAP1 and cIAP2 are structurally homologous with XIAP, with three BIR and one RING finger domain; however, they have a weaker binding affinity to caspase than does XIAP [59]. Livin and ILP-2 contain a RING finger and only one BIR domain [56]. Livin is highly expressed in melanoma and inhibits caspases 3 and 9 but not caspases 1, 2, 6, or 8 [60]. ILP-2 inhibits caspase 9, but not caspases 3, 7, or 8 [61].

\subsubsection{Class 2 IAPs}

The only member of class 2, NIAP, has three BIR domains but no RING finger motif [62]. It inhibits caspases 3 and 7, but not caspases 1, 4, 5, or 8 [63].

\subsubsection{Class 3 IAPs}

The very important and well-studied member of class 3 is survivin. Survivin contains a single BIR domain and no RING finger. Survivin is overexpressed in a variety of malignancies [64-68]. Since survivin is expressed in normal cells, the differential expression between normal and malignant cells can be exploited for therapeutic purposes.

\subsection{HSP Family}

HSPs are a ubiquitous family of molecular chaperones, classified into subfamilies according to their molecular size. The HSP subfamilies are HSP100, Hsp90, Hsp70, Hsp60, and small HSPs (size varying from 15 to $30 \mathrm{kDa}$ ) [69,70]. With adaptor molecules and co-chaperones, HSPs form a large multiprotein complex and regulate more than 200 proteins [71-73].

One of the most studied and characterized members of the HSP family is Hsp90. Hsp90 is highly conserved from unicellular organisms to mammals. High expression of Hsp90 is associated with many solid tumors and hematological malignancies. The overexpression Hsp90 has been linked with cancer cell survival and proliferation [74,75]. In addition, Hsp90 is required for the maturation and functional stability of various proteins essential for cancer cell immortality, survival, anti-apoptosis, metabolism, genomic instability, and metastasis [76]. Since its interacting partners are oncogenes, mutated genes, or proteins that are overexpressed in tumor cells and involved with tumorigenesis, Hsp90 represents a promising therapeutic target $[71,77,78]$.

\section{Inhibitors of Survival Proteins}

In the past several decades, the survival protein families have been targeted in cancer treatment strategies. Several types of survival protein-inhibiting agents have been developed, including antisense oligonucleotides (ASOs); peptides, small-molecule inhibitors, and nutraceuticals. Some such agents are under investigation in clinical trials, alone or combined with other therapies (Table 1).

\subsection{Inhibitors of Bcl-2 Proteins}

Multiple strategies have been adopted to target the Bcl-2 family members, including the use of peptides, small molecules, and ASOs. 
Table 1. A list of inhibitors of cell survival proteins identified as potential therapeutics at different stages of clinical development.

\begin{tabular}{|c|c|c|c|}
\hline Compound & Reference & Compound & Reference \\
\hline Bcl-2 inhibitor & & Survivin inhibitor & \\
\hline GX15-070** & [152] & LY2181308 ** & [153] \\
\hline HA-14 & [154] & Ad-Survivin T34A & [155] \\
\hline HA14-1 & [156] & EZN-3042* & [157] \\
\hline ВНЗІ-1/ВНЗІ-2 & {$[158]$} & SPC3042 & [159] \\
\hline 2-carboxyphenolate & [160] & YM155 ** & [161] \\
\hline Genasense *** & [85] & SF002-96-1 & [162] \\
\hline Polyphenon E ${ }^{* *}$ & {$[163]$} & Withanone & {$[164]$} \\
\hline SAHBs & [165] & GDP366 & [166] \\
\hline YC137 & [167] & Gambogic acid & [113] \\
\hline Tetrocarcin-A derivatives & {$[168]$} & Mcl-1 inhibitor & \\
\hline Bcl-xL inhibitor & & Maritoclax & [90] \\
\hline Chelerythrine & [169] & MIM-1 & [170] \\
\hline Compound 6 & [171] & BIR2 inhibitor & \\
\hline 2-Methoxyantimycin A3 & [172] & TWX024 & [173] \\
\hline BM-1197 & {$[174]$} & Survivin/XIAP/Mcl-1/cIAP2 inhibitor & \\
\hline BM-1074 & {$[175]$} & FL118 & [176] \\
\hline Compound 19/93 & [177] & HSP90 inhibitor & \\
\hline $\mathrm{Z} 36$ & [178] & SNX-25a & [179] \\
\hline 072RB & {$[180]$} & Novobiocin & {$[181]$} \\
\hline A-385358 & [182] & 17-DR & [183] \\
\hline Antisense (ISIS 15999) & {$[184]$} & Debio 0932 & [185] \\
\hline Antisense (ISIS 22783) & [186] & SNX-2112 & [187] \\
\hline Terphenyl derivatives & [188] & PU-H71 & [142] \\
\hline Meiogynin A & [189] & AT13387 & [190] \\
\hline$B C l-2 / B c l-x L$ inhibitor & & NMS-E973 & [191] \\
\hline Nativoclax $($ ABT-263) ** & [192] & NXD30001 & [193] \\
\hline ABT-199 ** & [194] & Geraniin & [195] \\
\hline Antimycin A & [92] & CH5164840 & [196] \\
\hline BM-957 & [197] & EGC-3-gallate & [198] \\
\hline ABT-737 & [199] & Oleocanthal & [200] \\
\hline Bcl-2/Bcl-xL/Mcl-1 inhibitor & & XL888 & [201] \\
\hline Gossypol (AT-101) ** & [148] & SNX-7081 & [202] \\
\hline BI-97C1 & [118] & NVP-HSP990 & [203] \\
\hline XIAP inhibitor & & Radicicol & [204] \\
\hline BIR3 antagonists & {$[205,206]$} & BJ-B11 & [207] \\
\hline PPU derivatives & [208] & KW-2478 & [209] \\
\hline Capped tripeptides 205 & & MPC-3100 & [210] \\
\hline SM-164 & [127] & Peptide PEP73 & [195] \\
\hline AEG35156 ** & [211] & AUY922 * & [212] \\
\hline Embelin & [213] & 17-DMAG * & [214] \\
\hline XIAP/BIR3 inhibitor & & SNX5422* & [215] \\
\hline GDC-0152 & [216] & BIIB021 ** & [217] \\
\hline IAIAP inhibitor & & $17-\mathrm{AAG}^{* *}$ & [218] \\
\hline LCL161 & [219] & Ganetespib ** & [220] \\
\hline OHРPA & [221] & IPI-504 ** & [222] \\
\hline Livin (ML-IAP) & [223] & & \\
\hline
\end{tabular}

* Phase I; ** Phase II; *** Phase III; Compound 6, (E)-2-(8-(2-(Benzo[d]thiazol-2-yl)hydrazono)-5,6,7,8-tetrahydron aphthalen-2-yl)-5-(4-phenylbutyl)thiazole-4-carboxylic acid; Compound 19/93, (R)-3-(amido indomethacin) -4-(naphthalen-1-yl)butanoic acid; SAHBs, stabilized alpha-helices of BCL-2 domains; 17-AAG, 17-allylamino, 17-demethoxygeldanamycin; 17-DR, 17-Demethoxy-reblastatin; EGC, Epigallocatechin; PPU, Polyphenylurea; OHPPA, octahydropyrrolo[1,2-a]pyrazine A. 


\subsubsection{Peptide-Based Inhibitors}

Sattler et al. provided first evidence that a BAX-BH3 peptide could inhibit the anti-apoptotic activity of Bcl-xL by binding to its hydrophobic groove [79]. Later studies of the crystal structure of all BH3-only proteins revealed that each BH3-only protein binds specifically with another anti-apoptotic protein. For example, the BH3-only protein NOXA can only bind with Mcl-1 [80]. This understanding of the intimate relationship of BH3-only proteins with anti-apoptotic proteins led to the discovery of several BH3 mimetic peptides. For example, a peptide derived from the nuclear receptor Nur77 was shown to bind between the $\mathrm{BH} 3$ and $\mathrm{BH} 4$ domains, unmasking the $\mathrm{BH} 3$ domain and leading to a functional switch of Bcl-2 from an anti-apoptotic to a pro-apoptotic protein [81]. Another strategy popularly known as "stapled peptides" was developed to target the BH3 domain of BIM, inhibiting Bcl-2-BIM interactions. This stapled peptide successfully overcomes apoptotic resistance in hematologic cancers [82]. These proof-of-principle studies are encouraging; however, a cautious approach and more studies are required before $\mathrm{BH} 3$ peptides can be widely adopted as therapeutic agents.

\subsubsection{ASOs}

First used against Bcl-2, ASOs are another tool to inhibit the expression of anti-apoptotic Bcl-2 family proteins $[83,84]$. ASOs are synthetic, short, single-stranded DNA molecules that can interfere with gene expression by forming a heteroduplex with complementary sequences within target messenger RNAs. Nonetheless, several attempts have been made successfully in this regard to develop specific ASO inhibitors against Bcl-2 family, and few of them are now in clinical trials. Phase II trials of oblimersen, also called G-3139, for the treatment of leukemia, lymphoma, and cancers of the prostate, colon, and breast are under way, as are phase III trials of its use against melanoma and myeloma [5]. However, oblimersen failed to get FDA approval for the treatment of relapsed or refractory chronic lymphocytic leukemia, since it did not show significant survival improvements compared with the standard of care for such in patients [85]. Combinations of ASOs with existing chemotherapeutic agents have shown the promise against several cancers [86-88]. Despite the encouraging results from recent studies, the use of ASOs is limited because of their non-specific binding and lack of stability [89].

\subsubsection{Small-Molecule Inhibitors}

Organic compounds smaller than 900 Da are considered small-molecule compounds. Because of their size, these smaller agents have greater potential than ASOs and peptides as Bcl-2 inhibitors. Several screening strategies have been adopted to find specific small-molecule inhibitors of anti-apoptotic Bcl-2 family members. Most small-molecule inhibitors have been developed as $\mathrm{BH} 3$ mimetics, since BH3 binding to the cleft of Bcl-2 are critical for Bcl-2's anti-apoptotic activities. Small-molecule inhibitors derived from natural products also have shown promising efficacy in variety of cancers [90-93]. ABT-737, navitoclax, obatoclax, maritoclax, gossypol and its derivatives, and BH3-M6 are some of the small-molecule inhibitors currently in preclinical and clinical phases of development (please see Table 1 and Figure 2).

To date, the BH3 mimetic ABT-737 and its orally active analogue navitoclax (also called ABT-263) are the most potent Bcl-2 and Bcl-xL inhibitors. As a single agent, ABT-737 is effective in several preclinical models and sensitizes tumors to radiation and chemotherapy [94-97]. Importantly, phase I/II clinical trials of navitoclax against several cancers have been encouraging [98-100]. However, recent studies suggest that cancer cells develop resistance to ABT-737 through the upregulation of Mcl-1 [101], and in many instances this resistance can be overcome by the downregulation of Mcl-1 $[90,91,102,103]$. Thus, the simultaneous targeting of Bcl-2 and Mcl-1 could improve patient outcomes. 
Bcl-2 inhibitors:

5'-TCTCCCAGCGTGCGCCAT-3'

Genasense
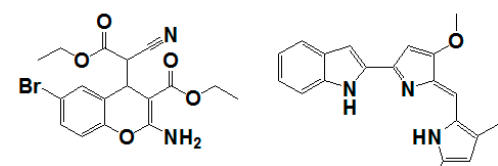

HA14-1

GX15-070

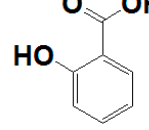

2-carboxyphenolate

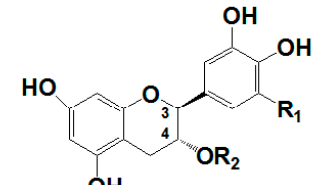

$\mathbf{G}=$

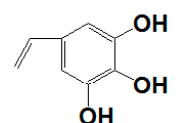

$\mathrm{OH}$

Component Abbrev.

\section{Component}

(-). Epicatechin

(-)-Epicatechin Gallate

(1). Epigallocatechin

$E C$
$E C g$
$E G C$

EGC

+t)-Gallocatechin

EGCg

$\mathrm{GC}$
$\mathrm{GC}$
$\mathrm{GCg}$

(1)-Gallocatechin Gallaro

+)-Catechin

(HCachin
$\begin{array}{lll}\mathbf{R}_{\mathbf{1}} & \mathbf{R}_{\mathbf{2}} \quad \mathrm{Rel}\end{array}$

$\begin{array}{lll}H & G & \text { cis } \\ \text { H } & 3 R, 4 R\end{array}$

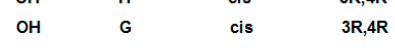

$\mathrm{OH} \mathrm{H}$ trans $3 \mathrm{R}, 4 \mathrm{~S}$

$\begin{array}{ll}\text { trans } & 3 R, 4 S \\ \text { trans } & 3 \mathrm{~S}, 4 \mathrm{R}\end{array}$

\begin{tabular}{cc} 
trans & $3 \mathrm{~S}, 4 \mathrm{R}$ \\
trans & $3 \mathrm{~s}, 4 \mathrm{R}$ \\
\hline
\end{tabular}

$\begin{array}{cc}\text { trans } & 3 S, 4 R \\ \text { trans } & 3 R, 4 S\end{array}$

$\begin{array}{ll}\text { trsns } & 3 S, 4 R \\ \text { trans } & 3 S, 4 R \\ & \end{array}$

Polyphenon E

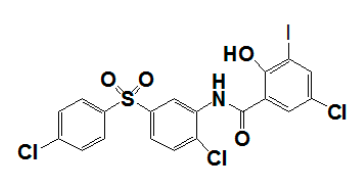

BH3I-2

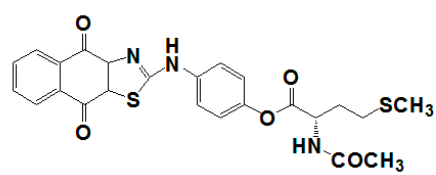

YC137

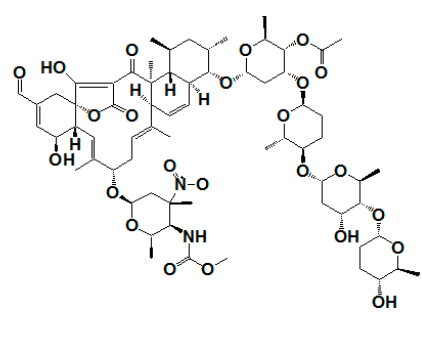

Tetrocarcin A
IAP inhibitors:

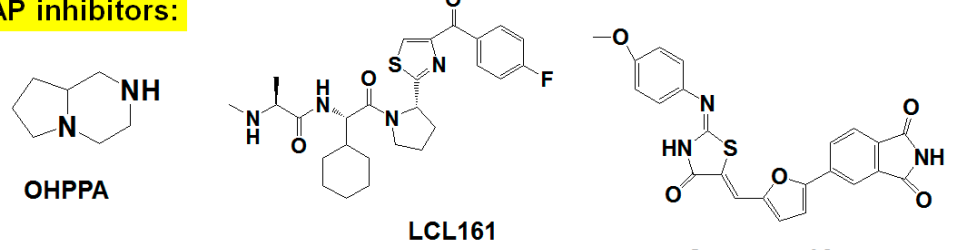

Compound 3

Survivin inhibitors:

5'-CTCAatccatggCAGC-3' EZN-3042

5'-TGTGCTATTCTGTGAATT-3'

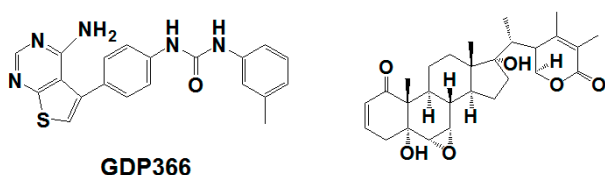
LY2181308

(1)

SF002-96-1

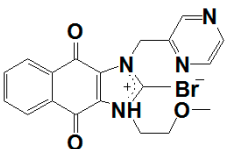

YM155

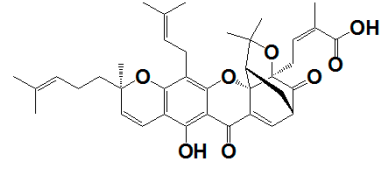

Gambogic acid

Figure 2. Cont. 
$\mathrm{Bcl}-\mathrm{xL}$ inhibitors:

$\mathrm{NH}_{2}$-DMRPEIYIAibQELRRIGDAFNAibY-COOH

072RB

5'-CTGGAT CCAAGGCTCTAGGT-3'

Antisense (ISIS 22783)

5'-TCCCGgTTGCTCTGAGACAT-3'

Antisense (ISIS 15999)

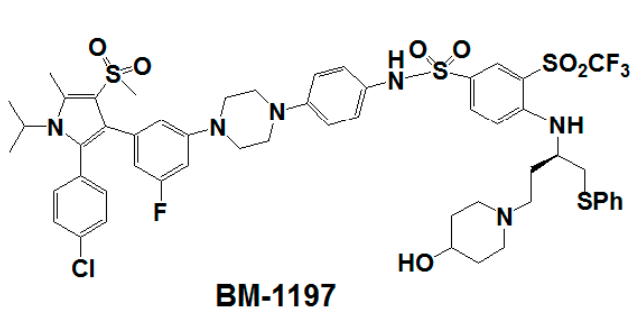

BM-1197

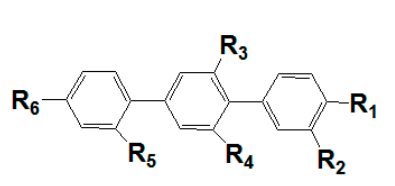

Terphenyl derivatives

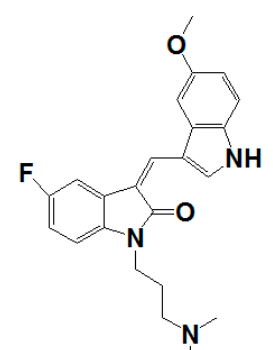

Z36

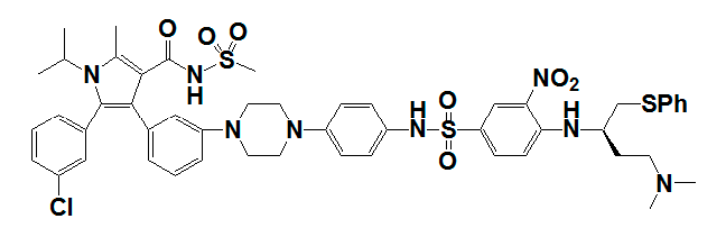

BM-1074
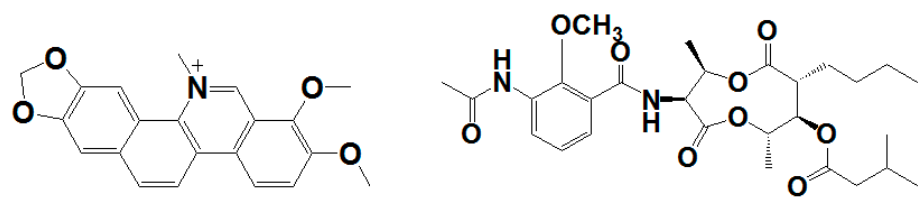

Chelerythrine

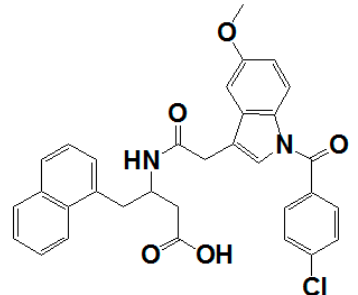

Compound 19/93

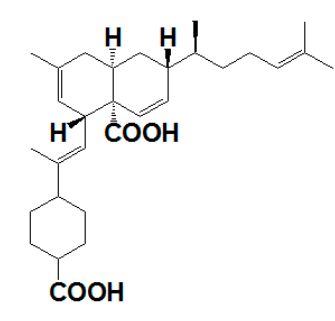

Meiogynin A

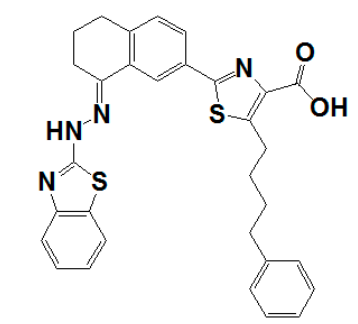

Compound 6

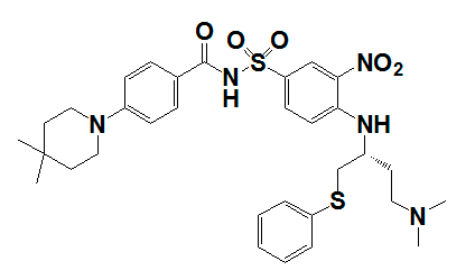

A-385358

Figure 2. Cont. 


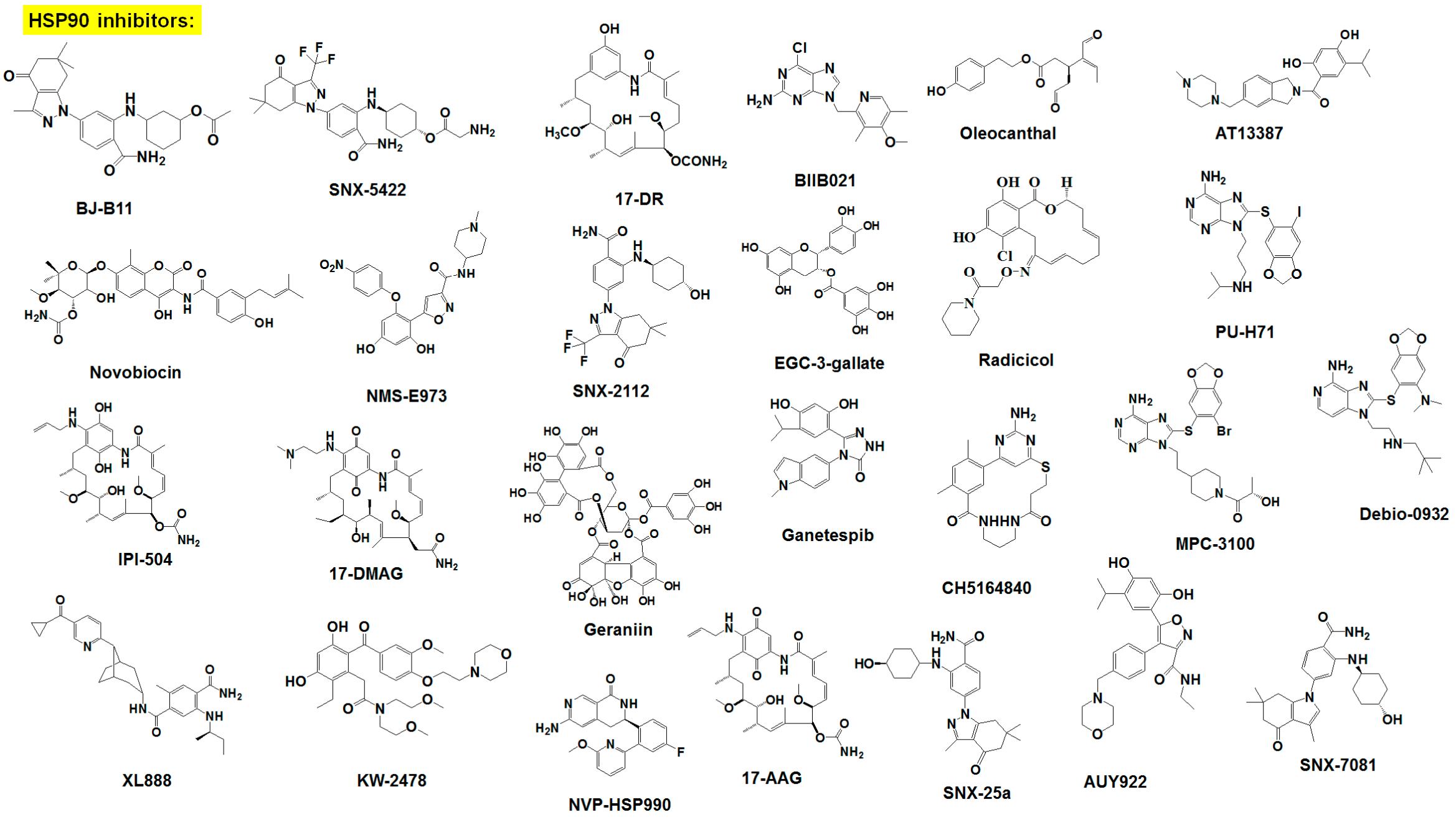

Figure 2. Cont. 
$\mathrm{Bcl}-2 / \mathrm{Bcl}-\mathrm{xL}$ inhibitors:

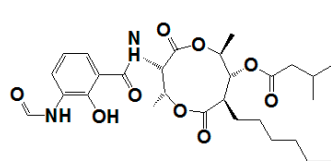

Antimycin A

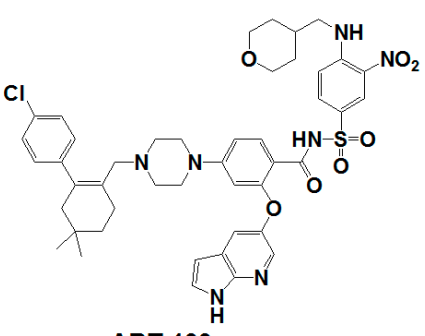

ABT-199

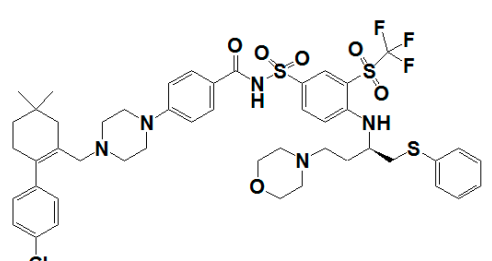

ABT-263

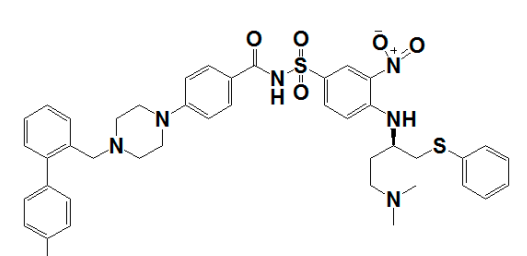

ABT-737

\section{Bcl-2/Bcl-xL/Mcl-1inhibitors:}

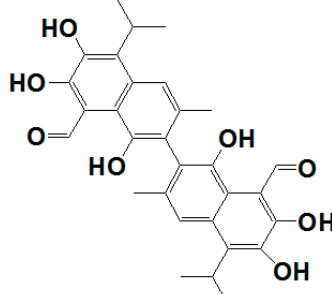

AT-101

BIR2 inhibitors:

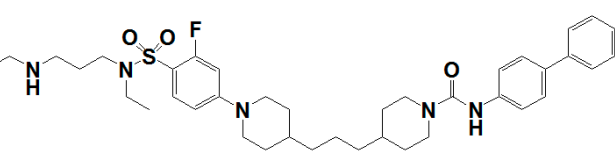

TWX024

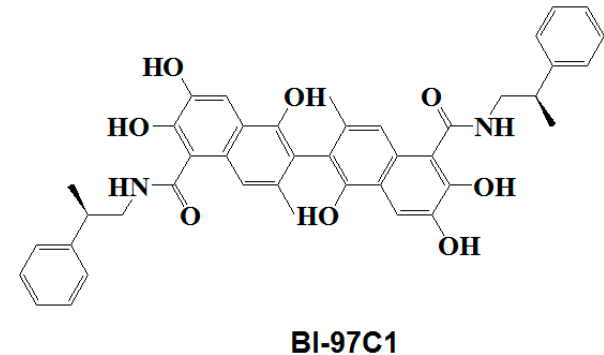

XIAP/BIR3 inhibitors:

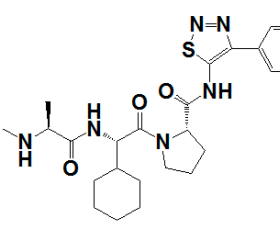

GDC-0152

XIAP inhibitors:

5'-(2'-OMe-RNA $)_{4}(\mathrm{DNA})_{11}\left(2^{\prime}-\mathrm{OMe}-\mathrm{RNA}\right)_{4}$-3' $^{\prime}$

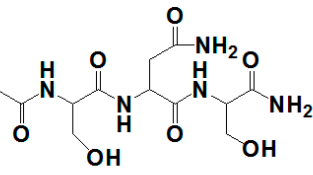

Capped tripeptides
AEG35156

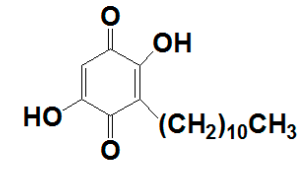

Embelin

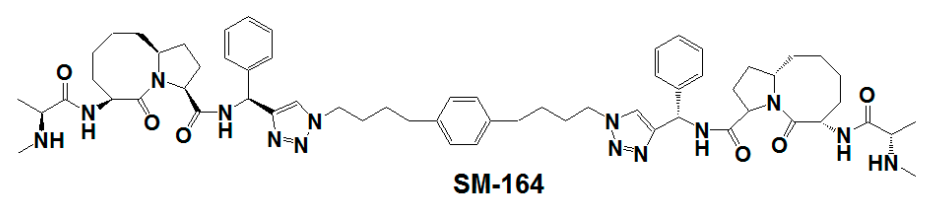

XAF1:

1 atggaaggag acttctcggt gtgcaggaac tgtaaaagac atgtagtctc tgccaacttc accctccatg

71 aggcttactg cctgcggttc ctggtcctgt gtccggagtg tgaggagcct gtccccaagg aaaccatgga

131 ggagcactgc aagcttgagc accagcaggt tgggtgtacg atgtgtcagc agagcatgca gaagtcctcg

191 ctggagtttc ataaggccaa tgagtgccag gagcgccctg ttgagtgtaa gttctgcaaa ctggacatgc

251 agctcagcaa gctggagctc cacgagtcct actgtggcag ccggacagag ctctgccaag gctgtggcca

311 gttcatcatgcaccgcatgc tcgcccagca cagagatgtc tgtcggagtg aacaggccca gctcgggaaa

371 ggggaaagaa tttcagctcc tgaaagggaa atctactgtc attattgcaa ccaaatgatt ccagaaaata

431 agtattcca ccatatgggt aaatgttgtc cagactcaga gtttaagaaa cactttctg ttggaaatcc

491 agaaattctt ccttcatctc ttccaagtca agctgctgaa aatcaaactt ccacgatgga gaaagatgtt

551 cgtccaaaga caagaagtat aaacagatt cctctcatt ctgaaag ttc atcaaagaaa gcaccaagaa

611 gcaaaaacaa aacct ggat ccacttiga ticagagcc caagcccagg accagctccc ctagaggaga

731 cagcace

791 tggaa

851 ggtggtcttg tgaaaggtga tgggttttat tcgttgggct ttaaaagaaa aggtttggca gaactaaaa

911 caaaactcac gtatcatctc attagataca gaaaaggctt ttgataaaat tcaacttgac ttcatgttaa

971 aaaccctca caaccac

1031 agccaacatc atactgaatg agcaaaagct ggagcattac tcttgagaag tagaacaagg cacttcagtc

1031 agccaacatc atactgaatg agcaaaagct ggagcattac tttgagaag tagaacaagg cacttcag
1091 ctattcaaca tagtactgga agtctcgcca cagcaatcag gcaagagaaa gaagtaaaag gcaccc

Mcl-1 inhibitors:

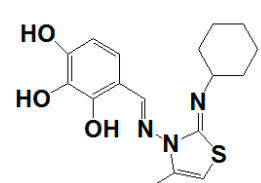

MIM-1

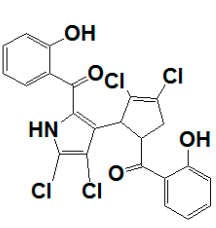

Maritoclax
Survivin/XIAP/Mcl-1/cIAP2 inhibitors:

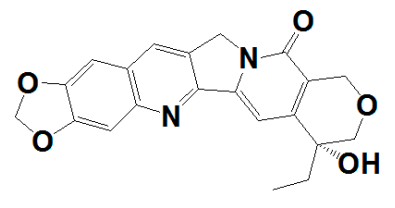

FL118

Figure 2. Chemical structure of survival family protein inhibitors. 
Obatoclax, also called GX015-070, is a pan-Bcl-2 inhibitor derived from prodiginines. Obatoclax inhibits the expression of Mcl-1 and other members of the Bcl-2 family. Studies have suggested that Obatoclax is effective against several cancers as single agent or combined with other agents [104-106]. Phase III clinical trials of obatoclax are ongoing; however, neurotoxicity caused by this agent may obstruct further progress [100,107,108].

Recently another Mcl-1 inhibitor, maritoclax (also called marinopyrrole A), was identified from marine species of streptomycetes [109]. Doi et al. suggested that maritoclax inhibits Mcl-1 via direct binding and proteasomal degradation [90]. Maritoclax was found to be effective in Mcl-1 overexpressing cells $[90,91,110]$. The discovery of maritoclax was exciting because the molecule binds specifically with Mcl-1 and increases the efficacy of ABT-737 in various cancer cells lines [91,110]; however, further pharmacokinetic studies are needed to translate this agent to clinic.

Gossypol was first identified as a male contraceptive in cottonseeds and is now being developed as an anticancer agent. Several studies have shown that gossypol and its derivatives bind to the hydrophobic grooves of Bcl-2 and Bcl-xL [111]; however, gossypol is not effective against Mcl-1. Gossypol is presently being investigated in clinical trials [112].

The second-generation benzenesulfonyl derivative of gossypol, TW-37, is a promising agent [113] that inhibits Bcl-2, Bcl-xL, and Mcl-1. Studies suggest that TW-37 is effective as single agent and potentiates the apoptotic effects of chemotherapeutic agents [114,115].

The third-generation of gossypol derivative, apogossypolone (also called ApoG2), also has been shown to inhibit Mcl-1 and other members of the Bcl-2 family. Preclinical studies suggest that apogossypolone is an effective agent against hematological malignancies [116].

A (-) enantiomer of gossypol, AT-101, has shown great promise against lymphoma. AT-101, currently studied in phase II clinical trials, is effective as single agent and potentiates the cytotoxic effects of several therapeutic agents [6,117].

Sabutoclax, also called BI-97C1, is the newest derivative of gossypol. Sabutoclax binds with Bcl-2, Mcl-1, and Bfl-1 with a better affinity than do other gossypol derivatives. In preclinical studies, sabutoclax was shown to induce apoptosis in ABT-737-resistant diffuse large B-cell lymphoma cells and to be effective in various cancer cell lines and xenograft models $[118,119]$.

Designed as a pan-Bcl-2 antagonist, BH3-M6 is the most recent BH3 mimetic. BH3-M6 inhibits proteins in the anti-apoptotic subfamily [120]. Further pharmacokinetic studies are required to fully evaluate this agent.

\subsection{Inhibitors of IAP Family Proteins}

Because of their constitutive expression in a variety of tumors, IAP family members have been attractive therapeutic targets. Among the strategies that have been explored to target IAP family members, the development of small-molecule antagonists has been the most studied. IAP antagonists either directly bind to IAP family proteins to prevent the proteins' binding to caspases and SMAC or stimulate ubiquitination and proteasomal degradation by inducing conformation changes [121,122]. The following IAPs antagonists have been or are currently being tested in preclinical or clinical studies.

\subsubsection{Selective IAP Inhibitors}

Because IAP family proteins differ in their structure and function, strategies have been adopted to selectively target individual members of IAP family. CS3 has been developed as selective antagonist of c-IAP1 and c-IAP2 $[47,123]$. Studies have suggested that CS3 degrades c-IAP1 and c-IAP2, but also activates the NF- $\mathrm{KB}$ signaling pathway; its therapeutic potential is therefore limited [123]. Another pan-selective IAP antagonist, PS1, has been shown to be a more potent antagonist than CS3 [123]. Recently, high-throughput screening identified TWX-024 as an XIAP-selective antagonist that disrupts XIAP-caspase 3 interaction [124]. 


\subsubsection{Inhibitors Mimicking SMAC}

The discovery of bivalent SMAC mimetic agents led to their development as a new class of IAP inhibitors [125]. These bivalent SMAC mimetics are made up of two monovalent units linked by a chemical structure [126] and have been shown to promote the dimerization of the BIR2-BIR3 domains of c-IAP1, as well as BIR3 constructs of XIAP [127]. Several studies have suggested that these SMAC mimetics inhibit cell proliferation and tumor growth [128].

\subsubsection{SMAC-Derived Peptides}

The characterization of SMAC and BIR domains led to the understanding of the precise region involved in the binding of peptides to selected BIR domains [129-131]. Once this mystery was solved, the synthesis of SMAC peptides became reality. Along these lines, peptides derived from the $\mathrm{N}$ terminus of mature active SMAC were found to mimic the activity of the SMAC protein and thus inhibit IAP proteins [132]. Further studies revealed that SMAC peptides blocked IAP-caspase interaction and sensitizes effects of TRAIL in the xenograft model $[133,134]$. Further studies and refinements of the pharmacological properties of SMAC peptides will be required before their use for the treatment of human cancers.

\subsection{Inhibitors of Hsp90}

The understanding of Hsp90 function and its association with cancer steered therapeutic scientists toward the development of Hsp90 inhibitors as a potential strategy for cancer treatment. A few Hsp90 inhibitors are currently being tested in the preclinical models, and some are under clinical investigation.

\subsubsection{Derivatives of Geldanamycin}

Geldanamycin, a benzoquinone ansamycin antibiotic, inhibits Hsp90 via binding to the ADP/ATP-binding pocket of the protein [71]. Because of its unfavorable pharmacological properties, which include hepatotoxicity and poor solubility, several attempts have been made to modify geldanamycin. By substituting a methoxy group for an allyl amino group, a geldanamycin derivative, tanespimycin (17-allylamino-17-demethoxy-geldanamycin; 17-AAG), was developed [135]. Studies have shown that tanespimycin, alone or in combination with chemotherapeutic drugs, is effective against a variety of cancers $[71,136]$. The manufacturer is engaged in further modification of this agent $[137,138]$.

\subsubsection{Resorcinol and Its Derivatives}

Resorcinol, a natural antibiotic that competes with ATP for Hsp90 binding, is a potent inhibitor of Hsp90. However, in vivo studies of resorcinol's efficacy were not encouraging; therefore, several attempts have been made to modify the antibiotic. Along those lines, several resorcinol derivatives have been developed, such as NVP-AUY922, AT-13387, STA-9090, and KW-2478 [139]. Studies suggest that these derivatives are more potent than resorcinol [140].

\subsubsection{Purine-Based Inhibitors}

Chiosis et al. revealed another potential Hsp90 inhibitor, PU-H71 [141]. PU-H71, a synthetic molecule that competes with ATP for the Hsp90 ATP binding pocket, was found to be efficacious against breast cancer [142]. BIIB021, CUDC-305, and NVP-BEP800 are derivatives of PU-H71 and have found to be efficacious against several cancers $[143,144]$. BIIB021 is now in clinical development [145].

\subsection{Natural Agents as Survival Protein Inhibitors}

For several decades it has been of great interest to identify and characterize potential anti-cancer agents derived from natural resources, particularly those derived from spices, fruits, and vegetables. Many spice-derived nutraceuticals have been shown to help induce apoptosis and reduce inflammation 
and levels of survival proteins. Extensive work from our group and others has found that ajoene, butein, curcumin, dihydroartemisinin, diosgenin, ellagic acid, embelin, emodin, epigallocatechin gallate, escin, eugenol, garcinol, genistein, geraniin, guggulsterone, resveratrol, rosmarinic acid, and zerumbone have great potential to inhibit various survival proteins.

Because these agents possess high antioxidant and anti-inflammatory properties and target multiple pathways, these agents are considered "magic bullets" [146]. For this reason, many researchers are trying to develop new drugs derived from natural sources. Some such natural-derived agents are already in clinical trials; these include curcumin and gossypol $[147,148]$.

Curcumin is the chief polyphenol in turmeric and is known to bring about apoptosis in cancer cells. Curcumin upregulates the pro-apoptotic proteins BIM, BAK, BAX, NOXA, and PUMA and downregulates the anti-apoptotic proteins Bcl-2 and Bcl-xL [146]. An in vitro study in human multiple myeloma cells demonstrated that curcumin downregulated survivin and Bcl-2 expression and upregulated BAX expression, leading to apoptosis [149]. Rosmarinic acid was shown to induce apoptosis and downregulate Bcl-2 in an in vitro study of human T-cell leukemia [150]. Several spice-derived nutraceuticals target caspases, which are necessary for apoptosis. Some natural compounds stimulate caspase activity while suppressing Bcl-2 or Bcl-xL expression. For example, in an in vitro study of human myelogenous leukemia cells, ajoene was shown to activate caspase- 3 and cleave Bcl-2 [151].

\section{Conclusions and Perspectives}

The large volume of studies in various cancers over recent decades has provided unequivocal evidence that the overexpression of survival proteins is associated with cancer cell proliferation, survival, and chemoresistance. However, further studies are required to understand the regulation of the survival proteins, their tissue dynamics, and resistance mechanisms. There is a persistent need to develop novel strategies and agents to combat the resistance to chemotherapy and radiation observed in cancers. The ultimate goal would be to develop a novel agent that could expel the surviving cancer cells that are primarily resistant to conventional therapies.

A major weakness of current survival protein-targeting therapy strategies is their inability to target all survival proteins with the same affinity. Another problem is the unfavorable pharmacological properties of some promising agents. Thus, it is very important to understand the role of each individual survival protein family. For example, most inhibitors of pro-survival Bcl-2 proteins are weak Mcl-1 inhibitors; therefore, treating with those agents may not provide any therapeutic advantage for cancers whose main driver is Mcl-1. Thus, targeting Bcl-2 along with Mcl-1 should be an attractive option; however, a very careful approach is needed to consider this strategy. High-throughput screening technologies coupled with bioinformatic approaches will continue to be employed in the coming years to develop novel drugs against crucial players in cancer development and progression. In our opinion, the future development of more targeted inhibitors that have higher and broader affinities for all the major survival proteins, as well as agents that regulate cancer-signaling pathways, should greatly improve patient survival and prevent tumor recurrence or resistance.

Acknowledgments: We thank Bryan F. Tutt for proofreading this review and providing valuable comments. This work was supported in part by grants from the Center for Targeted Therapy of the M.D. Anderson Cancer Center and from the Malaysian Palm Oil Board to B.B.A., and International Myeloma Foundation to M.K.P.

Author Contributions: M.K.P. and B.B.A. conceived and outlined the article; M.K.P, S.P., A.K.T, L.D. did literature search and wrote the article; J.H. drew the chemical structures, D.N.K. organized the tables, figures, and inserted the references; S.G.A. and B.B.A. critically evaluated and finalized the article.

Conflicts of Interest: The authors declare no conflict of interest. The founding sponsors had no role in the design of the study; in the collection, analyses, or interpretation of data; in the writing of the manuscript, and in the decision to publish the results. 


\section{References}

1. Tsujimoto, Y.; Cossman, J.; Jaffe, E.; Croce, C.M. Involvement of the bcl-2 gene in human follicular lymphoma. Science 1985, 228, 1440-1443. [CrossRef] [PubMed]

2. Reed, J.C.; Pellecchia, M. Apoptosis-based therapies for hematologic malignancies. Blood 2005, 106, 408-418. [CrossRef] [PubMed]

3. Packham, G.; Stevenson, F.K. Bodyguards and assassins: Bcl-2 family proteins and apoptosis control in chronic lymphocytic leukaemia. Immunology 2005, 114, 441-449. [CrossRef] [PubMed]

4. Kang, M.H.; Reynolds, C.P. Bcl-2 inhibitors: Targeting mitochondrial apoptotic pathways in cancer therapy. Clin. Cancer Res. 2009, 15, 1126-1132. [CrossRef] [PubMed]

5. Reed, J.C. Apoptosis-based therapies. Nat. Rev. Drug Discov. 2002, 1, 111-121. [CrossRef] [PubMed]

6. Thomas, S.; Quinn, B.A.; Das, S.K.; Dash, R.; Emdad, L.; Dasgupta, S.; Wang, X.Y.; Dent, P.; Reed, J.C.; Pellecchia, M.; et al. Targeting the bcl-2 family for cancer therapy. Expert Opin. Ther. Targets 2013, 17, 61-75. [CrossRef] [PubMed]

7. Reed, J.C. Bcl-2-family proteins and hematologic malignancies: History and future prospects. Blood 2008, 111, 3322-3330. [CrossRef] [PubMed]

8. Sinicrope, F.A.; Hart, J.; Michelassi, F.; Lee, J.J. Prognostic value of bcl-2 oncoprotein expression in stage II colon carcinoma. Clin. Cancer Res. 1995, 1, 1103-1110. [PubMed]

9. Jiang, S.X.; Sato, Y.; Kuwao, S.; Kameya, T. Expression of bcl-2 oncogene protein is prevalent in small cell lung carcinomas. J. Pathol. 1995, 177, 135-138. [CrossRef] [PubMed]

10. McDonnell, T.J.; Troncoso, P.; Brisbay, S.M.; Logothetis, C.; Chung, L.W.; Hsieh, J.T.; Tu, S.M.; Campbell, M.L. Expression of the protooncogene bcl-2 in the prostate and its association with emergence of androgen-independent prostate cancer. Cancer Res. 1992, 52, 6940-6944. [PubMed]

11. Joensuu, H.; Pylkkanen, L.; Toikkanen, S. Bcl-2 protein expression and long-term survival in breast cancer. Am. J. Pathol. 1994, 145, 1191-1198. [PubMed]

12. Campos, L.; Rouault, J.P.; Sabido, O.; Oriol, P.; Roubi, N.; Vasselon, C.; Archimbaud, E.; Magaud, J.P.; Guyotat, D. High expression of bcl-2 protein in acute myeloid leukemia cells is associated with poor response to chemotherapy. Blood 1993, 81, 3091-3096. [PubMed]

13. Hermine, O.; Haioun, C.; Lepage, E.; d'Agay, M.F.; Briere, J.; Lavignac, C.; Fillet, G.; Salles, G.; Marolleau, J.P.; Diebold, J.; et al. Prognostic significance of bcl-2 protein expression in aggressive non-hodgkin's lymphoma. Groupe d'etude des lymphomes de l'adulte (gela). Blood 1996, 87, 265-272. [PubMed]

14. Grover, R.; Wilson, G.D. Bcl-2 expression in malignant melanoma and its prognostic significance. Eur. J. Surg. Oncol. 1996, 22, 347-349. [CrossRef]

15. Weller, M.; Malipiero, U.; Aguzzi, A.; Reed, J.C.; Fontana, A. Protooncogene bcl-2 gene transfer abrogates Fas/APO-1 antibody-mediated apoptosis of human malignant glioma cells and confers resistance to chemotherapeutic drugs and therapeutic irradiation. J. Clin. Investig. 1995, 95, 2633-2643. [CrossRef] [PubMed]

16. Cimmino, A.; Calin, G.A.; Fabbri, M.; Iorio, M.V.; Ferracin, M.; Shimizu, M.; Wojcik, S.E.; Aqeilan, R.I.; Zupo, S.; Dono, M.; et al. Mir-15 and mir-16 induce apoptosis by targeting bcl2. Proc. Natl. Acad. Sci. USA 2005, 102, 13944-13949. [CrossRef] [PubMed]

17. Singh, R.; Saini, N. Downregulation of bcl2 by mirnas augments drug-induced apoptosis—a combined computational and experimental approach. J. Cell Sci. 2012, 125, 1568-1578. [CrossRef] [PubMed]

18. Rao, P.H.; Houldsworth, J.; Dyomina, K.; Parsa, N.Z.; Cigudosa, J.C.; Louie, D.C.; Popplewell, L.; Offit, K.; Jhanwar, S.C.; Chaganti, R.S. Chromosomal and gene amplification in diffuse large b-cell lymphoma. Blood 1998, 92, 234-240. [PubMed]

19. Hanada, M.; Delia, D.; Aiello, A.; Stadtmauer, E.; Reed, J.C. Bcl-2 gene hypomethylation and high-level expression in B-cell chronic lymphocytic leukemia. Blood 1993, 82, 1820-1828. [PubMed]

20. Yano, T.; Jaffe, E.S.; Longo, D.L.; Raffeld, M. Myc rearrangements in histologically progressed follicular lymphomas. Blood 1992, 80, 758-767. [PubMed]

21. Strasser, A.; Harris, A.W.; Bath, M.L.; Cory, S. Novel primitive lymphoid tumours induced in transgenic mice by cooperation between myc and bcl-2. Nature 1990, 348, 331-333. [CrossRef] [PubMed] 
22. Strasser, A.; Elefanty, A.G.; Harris, A.W.; Cory, S. Progenitor tumours from Emu-bcl-2-myc transgenic mice have lymphomyeloid differentiation potential and reveal developmental differences in cell survival. EMBO J. 1996, 15, 3823-3834. [PubMed]

23. Jager, R.; Herzer, U.; Schenkel, J.; Weiher, H. Overexpression of Bcl-2 inhibits alveolar cell apoptosis during involution and accelerates c-myc-induced tumorigenesis of the mammary gland in transgenic mice. Oncogene 1997, 15, 1787-1795. [CrossRef] [PubMed]

24. Naik, P.; Karrim, J.; Hanahan, D. The rise and fall of apoptosis during multistage tumorigenesis: Down-modulation contributes to tumor progression from angiogenic progenitors. Genes Dev. 1996, 10, 2105-2116. [CrossRef] [PubMed]

25. Boise, L.H.; Gonzalez-Garcia, M.; Postema, C.E.; Ding, L.; Lindsten, T.; Turka, L.A.; Mao, X.; Nunez, G.; Thompson, C.B. Bcl-x, a bcl-2-related gene that functions as a dominant regulator of apoptotic cell death. Cell 1993, 74, 597-608. [CrossRef]

26. Kirsh, E.J.; Baunoch, D.A.; Stadler, W.M. Expression of bcl-2 and bcl-x in bladder cancer. J. Urol. 1998, 159, 1348-1353. [CrossRef]

27. Castilla, C.; Congregado, B.; Chinchon, D.; Torrubia, F.J.; Japon, M.A.; Saez, C. Bcl-xl is overexpressed in hormone-resistant prostate cancer and promotes survival of lncap cells via interaction with proapoptotic bak. Endocrinology 2006, 147, 4960-4967. [CrossRef] [PubMed]

28. Kozopas, K.M.; Yang, T.; Buchan, H.L.; Zhou, P.; Craig, R.W. Mcl1, a gene expressed in programmed myeloid cell differentiation, has sequence similarity to bcl2. Proc. Natl. Acad. Sci. USA 1993, 90, 3516-3520. [CrossRef] [PubMed]

29. Day, C.L.; Smits, C.; Fan, F.C.; Lee, E.F.; Fairlie, W.D.; Hinds, M.G. Structure of the BH3 domains from the p53-inducible BH3-only proteins Noxa and Puma in complex with mcl-1. J. Mol. Biol. 2008, 380, 958-971. [CrossRef] [PubMed]

30. Rinkenberger, J.L.; Horning, S.; Klocke, B.; Roth, K.; Korsmeyer, S.J. Mcl-1 deficiency results in peri-implantation embryonic lethality. Genes Dev. 2000, 14, 23-27. [PubMed]

31. Opferman, J.T.; Iwasaki, H.; Ong, C.C.; Suh, H.; Mizuno, S.; Akashi, K.; Korsmeyer, S.J. Obligate role of anti-apoptotic mcl-1 in the survival of hematopoietic stem cells. Science 2005, 307, 1101-1104. [CrossRef] [PubMed]

32. Opferman, J.T.; Letai, A.; Beard, C.; Sorcinelli, M.D.; Ong, C.C.; Korsmeyer, S.J. Development and maintenance of B and T lymphocytes requires antiapoptotic MCL-1. Nature 2003, 426, 671-676. [CrossRef] [PubMed]

33. Arbour, N.; Vanderluit, J.L.; Le Grand, J.N.; Jahani-Asl, A.; Ruzhynsky, V.A.; Cheung, E.C.; Kelly, M.A.; MacKenzie, A.E.; Park, D.S.; Opferman, J.T.; et al. Mcl-1 is a key regulator of apoptosis during CNS development and after DNA damage. J. Neurosci. 2008, 28, 6068-6078. [CrossRef] [PubMed]

34. Perciavalle, R.M.; Opferman, J.T. Delving deeper: Mcl-1's contributions to normal and cancer biology. Trends Cell Biol. 2013, 23, 22-29. [CrossRef] [PubMed]

35. Beroukhim, R.; Mermel, C.H.; Porter, D.; Wei, G.; Raychaudhuri, S.; Donovan, J.; Barretina, J.; Boehm, J.S.; Dobson, J.; Urashima, M.; et al. The landscape of somatic copy-number alteration across human cancers. Nature 2010, 463, 899-905. [CrossRef] [PubMed]

36. Glaser, S.P.; Lee, E.F.; Trounson, E.; Bouillet, P.; Wei, A.; Fairlie, W.D.; Izon, D.J.; Zuber, J.; Rappaport, A.R.; Herold, M.J.; et al. Anti-apoptotic mcl-1 is essential for the development and sustained growth of acute myeloid leukemia. Genes Dev. 2012, 26, 120-125. [CrossRef] [PubMed]

37. Wei, L.H.; Kuo, M.L.; Chen, C.A.; Chou, C.H.; Cheng, W.F.; Chang, M.C.; Su, J.L.; Hsieh, C.Y. The anti-apoptotic role of interleukin-6 in human cervical cancer is mediated by up-regulation of mcl-1 through a pi 3-k/akt pathway. Oncogene 2001, 20, 5799-5809. [CrossRef] [PubMed]

38. Shigemasa, K.; Katoh, O.; Shiroyama, Y.; Mihara, S.; Mukai, K.; Nagai, N.; Ohama, K. Increased mcl-1 expression is associated with poor prognosis in ovarian carcinomas. Jpn. J. Cancer Res. 2002, 93, 542-550. [CrossRef] [PubMed]

39. Stewart, D.P.; Koss, B.; Bathina, M.; Perciavalle, R.M.; Bisanz, K.; Opferman, J.T. Ubiquitin-independent degradation of antiapoptotic mcl-1. Mol. Cell. Biol. 2010, 30, 3099-3110. [CrossRef] [PubMed]

40. Zhong, Q.; Gao, W.; Du, F.; Wang, X. Mule/ARF-BP1, a BH3-only E3 ubiquitin ligase, catalyzes the polyubiquitination of mcl-1 and regulates apoptosis. Cell 2005, 121, 1085-1095. [CrossRef] [PubMed] 
41. Schwickart, M.; Huang, X.; Lill, J.R.; Liu, J.; Ferrando, R.; French, D.M.; Maecker, H.; O’Rourke, K.; Bazan, F.; Eastham-Anderson, J.; et al. Deubiquitinase USP9X stabilizes MCL1 and promotes tumour cell survival. Nature 2010, 463, 103-107. [CrossRef] [PubMed]

42. Inuzuka, H.; Shaik, S.; Onoyama, I.; Gao, D.; Tseng, A.; Maser, R.S.; Zhai, B.; Wan, L.; Gutierrez, A.; Lau, A.W.; et al. SCF ${ }^{\mathrm{FBW} 7}$ regulates cellular apoptosis by targeting MCL1 for ubiquitylation and destruction. Nature 2011, 471, 104-109. [CrossRef] [PubMed]

43. Rampino, N.; Yamamoto, H.; Ionov, Y.; Li, Y.; Sawai, H.; Reed, J.C.; Perucho, M. Somatic frameshift mutations in the bax gene in colon cancers of the microsatellite mutator phenotype. Science 1997, 275, 967-969. [CrossRef] [PubMed]

44. Meijerink, J.P.; Raemaekers, J.M.; Mensink, E.J. New type of $\mathrm{t}(14 ; 18)$ in a non-Hodgkin's lymphoma provides insight in molecular events in early B-cell differentiation. Br. J. Haematol. 1995, 91, 630-639. [CrossRef] [PubMed]

45. Shibue, T.; Takeda, K.; Oda, E.; Tanaka, H.; Murasawa, H.; Takaoka, A.; Morishita, Y.; Akira, S.; Taniguchi, T.; Tanaka, N. Integral role of Noxa in p53-mediated apoptotic response. Genes Dev. 2003, 17, 2233-2238. [CrossRef] [PubMed]

46. Nakano, K.; Vousden, K.H. Puma, a novel proapoptotic gene, is induced by p53. Mol. Cell 2001, 7, 683-694. [CrossRef]

47. Fulda, S.; Vucic, D. Targeting IAP proteins for therapeutic intervention in cancer. Nat. Rev. Drug Discov. 2012, 11, 109-124. [CrossRef] [PubMed]

48. Birnbaum, M.J.; Clem, R.J.; Miller, L.K. An apoptosis-inhibiting gene from a nuclear polyhedrosis virus encoding a polypeptide with cys/his sequence motifs. J. Virol. 1994, 68, 2521-2528. [PubMed]

49. Crook, N.E.; Clem, R.J.; Miller, L.K. An apoptosis-inhibiting baculovirus gene with a zinc finger-like motif. J. Virol. 1993, 67, 2168-2174. [PubMed]

50. Salvesen, G.S.; Duckett, C.S. IAP proteins: Blocking the road to death's door. Nat. Rev. Mol. Cell Biol. 2002, 3, 401-410. [CrossRef] [PubMed]

51. Sanna, M.G.; da Silva Correia, J.; Ducrey, O.; Lee, J.; Nomoto, K.; Schrantz, N.; Deveraux, Q.L.; Ulevitch, R.J. IAP suppression of apoptosis involves distinct mechanisms: The TAK1/JNK1 signaling cascade and caspase inhibition. Mol. Cell. Biol. 2002, 22, 1754-1766. [CrossRef] [PubMed]

52. Hofer-Warbinek, R.; Schmid, J.A.; Stehlik, C.; Binder, B.R.; Lipp, J.; de Martin, R. Activation of NF-kb by XIAP, the X chromosome-linked inhibitor of apoptosis, in endothelial cells involves TAK1. J. Biol. Chem. 2000, 275, 22064-22068. [CrossRef] [PubMed]

53. Levkau, B.; Garton, K.J.; Ferri, N.; Kloke, K.; Nofer, J.R.; Baba, H.A.; Raines, E.W.; Breithardt, G. XIAP induces cell-cycle arrest and activates nuclear factor-kb: New survival pathways disabled by caspase-mediated cleavage during apoptosis of human endothelial cells. Circ. Res. 2001, 88, 282-290. [CrossRef] [PubMed]

54. Varfolomeev, E.; Vucic, D. (Un)expected roles of c-IAPs in apoptotic and nfkappab signaling pathways. Cell Cycle 2008, 7, 1511-1521. [CrossRef] [PubMed]

55. Vaux, D.L.; Silke, J. Iaps, rings and ubiquitylation. Nat. Rev. Mol. Cell. Biol. 2005, 6, 287-297. [CrossRef] [PubMed]

56. Schimmer, A.D. Inhibitor of apoptosis proteins: Translating basic knowledge into clinical practice. Cancer Res. 2004, 64, 7183-7190. [CrossRef] [PubMed]

57. Duckett, C.S.; Nava, V.E.; Gedrich, R.W.; Clem, R.J.; Van Dongen, J.L.; Gilfillan, M.C.; Shiels, H.; Hardwick, J.M.; Thompson, C.B. A conserved family of cellular genes related to the baculovirus iap gene and encoding apoptosis inhibitors. EMBO J. 1996, 15, 2685-2694. [PubMed]

58. Deveraux, Q.L.; Leo, E.; Stennicke, H.R.; Welsh, K.; Salvesen, G.S.; Reed, J.C. Cleavage of human inhibitor of apoptosis protein XIAP results in fragments with distinct specificities for caspases. EMBO J. 1999, 18, 5242-5251. [CrossRef] [PubMed]

59. Deveraux, Q.L.; Roy, N.; Stennicke, H.R.; Van Arsdale, T.; Zhou, Q.; Srinivasula, S.M.; Alnemri, E.S.; Salvesen, G.S.; Reed, J.C. IAPs block apoptotic events induced by caspase- 8 and cytochrome c by direct inhibition of distinct caspases. EMBO J. 1998, 17, 2215-2223. [CrossRef] [PubMed]

60. Vucic, D.; Stennicke, H.R.; Pisabarro, M.T.; Salvesen, G.S.; Dixit, V.M. Ml-IAP, a novel inhibitor of apoptosis that is preferentially expressed in human melanomas. Curr. Biol. 2000, 10, 1359-1366. [CrossRef] 
61. Richter, B.W.; Mir, S.S.; Eiben, L.J.; Lewis, J.; Reffey, S.B.; Frattini, A.; Tian, L.; Frank, S.; Youle, R.J.; Nelson, D.L.; et al. Molecular cloning of ILP-2, a novel member of the inhibitor of apoptosis protein family. Mol. Cell. Biol. 2001, 21, 4292-4301. [CrossRef] [PubMed]

62. Roy, N.; Mahadevan, M.S.; McLean, M.; Shutler, G.; Yaraghi, Z.; Farahani, R.; Baird, S.; Besner-Johnston, A.; Lefebvre, C.; Kang, X.; et al. The gene for neuronal apoptosis inhibitory protein is partially deleted in individuals with spinal muscular atrophy. Cell 1995, 80, 167-178. [CrossRef]

63. Maier, J.K.; Lahoua, Z.; Gendron, N.H.; Fetni, R.; Johnston, A.; Davoodi, J.; Rasper, D.; Roy, S.; Slack, R.S.; Nicholson, D.W.; et al. The neuronal apoptosis inhibitory protein is a direct inhibitor of caspases 3 and 7. J. Neurosci. 2002, 22, 2035-2043. [PubMed]

64. Tanaka, K.; Iwamoto, S.; Gon, G.; Nohara, T.; Iwamoto, M.; Tanigawa, N. Expression of survivin and its relationship to loss of apoptosis in breast carcinomas. Clin. Cancer Res. 2000, 6, 127-134. [PubMed]

65. Gianani, R.; Jarboe, E.; Orlicky, D.; Frost, M.; Bobak, J.; Lehner, R.; Shroyer, K.R. Expression of survivin in normal, hyperplastic, and neoplastic colonic mucosa. Hum. Pathol. 2001, 32, 119-125. [CrossRef] [PubMed]

66. Sarela, A.I.; Macadam, R.C.; Farmery, S.M.; Markham, A.F.; Guillou, P.J. Expression of the antiapoptosis gene, survivin, predicts death from recurrent colorectal carcinoma. Gut 2000, 46, 645-650. [CrossRef] [PubMed]

67. Grabowski, P.; Kuhnel, T.; Muhr-Wilkenshoff, F.; Heine, B.; Stein, H.; Hopfner, M.; Germer, C.T.; Scherubl, H. Prognostic value of nuclear survivin expression in oesophageal squamous cell carcinoma. Br. J. Cancer 2003, 88, 115-119. [CrossRef] [PubMed]

68. Ambrosini, G.; Adida, C.; Altieri, D.C. A novel anti-apoptosis gene, survivin, expressed in cancer and lymphoma. Nat. Med. 1997, 3, 917-921. [CrossRef] [PubMed]

69. Powers, M.V.; Workman, P. Inhibitors of the heat shock response: Biology and pharmacology. FEBS Lett. 2007, 581, 3758-3769. [CrossRef] [PubMed]

70. Young, J.C.; Agashe, V.R.; Siegers, K.; Hartl, F.U. Pathways of chaperone-mediated protein folding in the cytosol. Nat. Rev. Mol. Cell Biol. 2004, 5, 781-791. [CrossRef] [PubMed]

71. Scaltriti, M.; Dawood, S.; Cortes, J. Molecular pathways: Targeting hsp90-who benefits and who does not. Clin. Cancer Res. 2012, 18, 4508-4513. [CrossRef] [PubMed]

72. Banerji, U. Heat shock protein 90 as a drug target: Some like it hot. Clin. Cancer Res. 2009, 15, 9-14. [CrossRef] [PubMed]

73. Whitesell, L.; Lindquist, S.L. Hsp90 and the chaperoning of cancer. Nat. Rev. Cancer 2005, 5, 761-772. [CrossRef] [PubMed]

74. Pick, E.; Kluger, Y.; Giltnane, J.M.; Moeder, C.; Camp, R.L.; Rimm, D.L.; Kluger, H.M. High hsp90 expression is associated with decreased survival in breast cancer. Cancer Res. 2007, 67, 2932-2937. [CrossRef] [PubMed]

75. Conroy, S.E.; Latchman, D.S. Do heat shock proteins have a role in breast cancer? Br. J. Cancer 1996, 74, 717-721. [CrossRef] [PubMed]

76. Taipale, M.; Jarosz, D.F.; Lindquist, S. Hsp90 at the hub of protein homeostasis: Emerging mechanistic insights. Nat. Rev. Mol. Cell Biol. 2010, 11, 515-528. [CrossRef] [PubMed]

77. Biamonte, M.A.; Van de Water, R.; Arndt, J.W.; Scannevin, R.H.; Perret, D.; Lee, W.C. Heat shock protein 90: Inhibitors in clinical trials. J. Med. Chem. 2010, 53, 3-17. [CrossRef] [PubMed]

78. Neckers, L.; Workman, P. Hsp90 molecular chaperone inhibitors: Are we there yet? Clin. Cancer Res. 2012, 18, 64-76. [CrossRef] [PubMed]

79. Sattler, M.; Liang, H.; Nettesheim, D.; Meadows, R.P.; Harlan, J.E.; Eberstadt, M.; Yoon, H.S.; Shuker, S.B.; Chang, B.S.; Minn, A.J.; et al. Structure of bcl-xl-bak peptide complex: Recognition between regulators of apoptosis. Science 1997, 275, 983-986. [CrossRef] [PubMed]

80. Willis, S.N.; Chen, L.; Dewson, G.; Wei, A.; Naik, E.; Fletcher, J.I.; Adams, J.M.; Huang, D.C. Proapoptotic bak is sequestered by mcl-1 and bcl-xl, but not bcl-2, until displaced by BH3-only proteins. Genes Dev. 2005, 19, 1294-1305. [CrossRef] [PubMed]

81. Kolluri, S.K.; Zhu, X.; Zhou, X.; Lin, B.; Chen, Y.; Sun, K.; Tian, X.; Town, J.; Cao, X.; Lin, F.; et al. A short nur77-derived peptide converts bcl-2 from a protector to a killer. Cancer Cell 2008, 14, 285-298. [CrossRef] [PubMed]

82. LaBelle, J.L.; Katz, S.G.; Bird, G.H.; Gavathiotis, E.; Stewart, M.L.; Lawrence, C.; Fisher, J.K.; Godes, M.; Pitter, K.; Kung, A.L.; et al. A stapled bim peptide overcomes apoptotic resistance in hematologic cancers. J. Clin. Investig. 2012, 122, 2018-2031. [CrossRef] [PubMed] 
83. Reed, J.C.; Stein, C.; Subasinghe, C.; Haldar, S.; Croce, C.M.; Yum, S.; Cohen, J. Antisense-mediated inhibition of bcl 2 protooncogene expression and leukemic cell growth and survival: Comparisons of phosphodiester and phosphorothioate oligodeoxynucleotides. Cancer Res. 1990, 50, 6565-6570. [PubMed]

84. Olie, R.A.; Zangemeister-Wittke, U. Targeting tumor cell resistance to apoptosis induction with antisense oligonucleotides: Progress and therapeutic potential. Drug Resist. Updates 2001, 4, 9-15. [CrossRef] [PubMed]

85. O’Brien, S.; Moore, J.O.; Boyd, T.E.; Larratt, L.M.; Skotnicki, A.B.; Koziner, B.; Chanan-Khan, A.A.; Seymour, J.F.; Gribben, J.; Itri, L.M.; et al. 5-year survival in patients with relapsed or refractory chronic lymphocytic leukemia in a randomized, phase III trial of fludarabine plus cyclophosphamide with or without oblimersen. J. Clin. Oncol. 2009, 27, 5208-5212. [CrossRef] [PubMed]

86. Bedikian, A.Y.; Millward, M.; Pehamberger, H.; Conry, R.; Gore, M.; Trefzer, U.; Pavlick, A.C.; DeConti, R.; Hersh, E.M.; Hersey, P.; et al. Bcl-2 antisense (oblimersen sodium) plus dacarbazine in patients with advanced melanoma: The oblimersen melanoma study group. J. Clin. Oncol. 2006, 24, 4738-4745. [CrossRef] [PubMed]

87. Zangemeister-Wittke, U.; Leech, S.H.; Olie, R.A.; Simoes-Wust, A.P.; Gautschi, O.; Luedke, G.H.; Natt, F.; Haner, R.; Martin, P.; Hall, J.; et al. A novel bispecific antisense oligonucleotide inhibiting both bcl-2 and bcl-xl expression efficiently induces apoptosis in tumor cells. Clin. Cancer Res. 2000, 6, 2547-2555. [PubMed]

88. Sieghart, W.; Losert, D.; Strommer, S.; Cejka, D.; Schmid, K.; Rasoul-Rockenschaub, S.; Bodingbauer, M.; Crevenna, R.; Monia, B.P.; Peck-Radosavljevic, M.; et al. Mcl-1 overexpression in hepatocellular carcinoma: A potential target for antisense therapy. J. Hepatol. 2006, 44, 151-157. [CrossRef] [PubMed]

89. Dean, N.M.; Bennett, C.F. Antisense oligonucleotide-based therapeutics for cancer. Oncogene 2003, 22, 9087-9096. [CrossRef] [PubMed]

90. Doi, K.; Li, R.; Sung, S.S.; Wu, H.; Liu, Y.; Manieri, W.; Krishnegowda, G.; Awwad, A.; Dewey, A.; Liu, X.; et al. Discovery of marinopyrrole A (maritoclax) as a selective Mcl-1 antagonist that overcomes ABT-737 resistance by binding to and targeting Mcl-1 for proteasomal degradation. J. Biol. Chem. 2012, 287, 10224-10235. [CrossRef]

91. Pandey, M.K.; Gowda, K.; Doi, K.; Sharma, A.K.; Wang, H.G.; Amin, S. Proteasomal degradation of Mcl-1 by maritoclax induces apoptosis and enhances the efficacy of ABT-737 in melanoma cells. PLoS ONE 2013, 8. [CrossRef]

92. Tzung, S.P.; Kim, K.M.; Basanez, G.; Giedt, C.D.; Simon, J.; Zimmerberg, J.; Zhang, K.Y.; Hockenbery, D.M. Antimycin a mimics a cell-death-inducing bcl-2 homology domain 3. Nat. Cell Biol. 2001, 3, 183-191. [CrossRef] [PubMed]

93. Kitada, S.; Leone, M.; Sareth, S.; Zhai, D.; Reed, J.C.; Pellecchia, M. Discovery, characterization, and structure-activity relationships studies of proapoptotic polyphenols targeting B-cell lymphocyte/leukemia-2 proteins. J. Med. Chem. 2003, 46, 4259-4264. [CrossRef] [PubMed]

94. Witham, J.; Valenti, M.R.; De-Haven-Brandon, A.K.; Vidot, S.; Eccles, S.A.; Kaye, S.B.; Richardson, A. The bcl-2/bcl-xl family inhibitor ABT-737 sensitizes ovarian cancer cells to carboplatin. Clin. Cancer Res. 2007, 13, 7191-7198. [CrossRef] [PubMed]

95. Hikita, H.; Takehara, T.; Shimizu, S.; Kodama, T.; Shigekawa, M.; Iwase, K.; Hosui, A.; Miyagi, T.; Tatsumi, T.; Ishida, H.; et al. The bcl-xl inhibitor, ABT-737, efficiently induces apoptosis and suppresses growth of hepatoma cells in combination with sorafenib. Hepatology 2010, 52, 1310-1321. [CrossRef] [PubMed]

96. Hann, C.L.; Daniel, V.C.; Sugar, E.A.; Dobromilskaya, I.; Murphy, S.C.; Cope, L.; Lin, X.; Hierman, J.S.; Wilburn, D.L.; Watkins, D.N.; et al. Therapeutic efficacy of ABT-737, a selective inhibitor of bcl-2, in small cell lung cancer. Cancer Res. 2008, 68, 2321-2328. [CrossRef] [PubMed]

97. Oltersdorf, T.; Elmore, S.W.; Shoemaker, A.R.; Armstrong, R.C.; Augeri, D.J.; Belli, B.A.; Bruncko, M.; Deckwerth, T.L.; Dinges, J.; Hajduk, P.J.; et al. An inhibitor of bcl-2 family proteins induces regression of solid tumours. Nature 2005, 435, 677-681. [CrossRef] [PubMed]

98. Roberts, A.W.; Seymour, J.F.; Brown, J.R.; Wierda, W.G.; Kipps, T.J.; Khaw, S.L.; Carney, D.A.; He, S.Z.; Huang, D.C.; Xiong, H.; et al. Substantial susceptibility of chronic lymphocytic leukemia to bcl2 inhibition: Results of a phase I study of navitoclax in patients with relapsed or refractory disease. J. Clin. Oncol. 2012, 30, 488-496. [CrossRef] [PubMed]

99. Wilson, W.H.; O'Connor, O.A.; Czuczman, M.S.; LaCasce, A.S.; Gerecitano, J.F.; Leonard, J.P.; Tulpule, A.; Dunleavy, K.; Xiong, H.; Chiu, Y.L.; et al. Navitoclax, a targeted high-affinity inhibitor of bcl-2, in lymphoid malignancies: A phase 1 dose-escalation study of safety, pharmacokinetics, pharmacodynamics, and antitumour activity. Lancet Oncol. 2010, 11, 1149-1159. [CrossRef] 
100. Billard, C. BH3 mimetics: Status of the field and new developments. Mol. Cancer Ther. 2013, 12, 1691-1700. [CrossRef] [PubMed]

101. Yecies, D.; Carlson, N.E.; Deng, J.; Letai, A. Acquired resistance to ABT-737 in lymphoma cells that up-regulate MCL-1 and BFL-1. Blood 2010, 115, 3304-3313. [CrossRef] [PubMed]

102. Van Delft, M.F.; Wei, A.H.; Mason, K.D.; Vandenberg, C.J.; Chen, L.; Czabotar, P.E.; Willis, S.N.; Scott, C.L.; Day, C.L.; Cory, S.; et al. The BH3 mimetic ABT-737 targets selective bcl-2 proteins and efficiently induces apoptosis via Bak/Bax if mcl-1 is neutralized. Cancer Cell 2006, 10, 389-399. [CrossRef]

103. Lucas, K.M.; Mohana-Kumaran, N.; Lau, D.; Zhang, X.D.; Hersey, P.; Huang, D.C.; Weninger, W.; Haass, N.K.; Allen, J.D. Modulation of Noxa and mcl-1 as a strategy for sensitizing melanoma cells to the BH3-mimetic ABT-737. Clin. Cancer Res. 2012, 18, 783-795. [CrossRef] [PubMed]

104. Smoot, R.L.; Blechacz, B.R.; Werneburg, N.W.; Bronk, S.F.; Sinicrope, F.A.; Sirica, A.E.; Gores, G.J. A Bax-mediated mechanism for obatoclax-induced apoptosis of cholangiocarcinoma cells. Cancer Res. 2010, 70, 1960-1969. [CrossRef] [PubMed]

105. Konopleva, M.; Watt, J.; Contractor, R.; Tsao, T.; Harris, D.; Estrov, Z.; Bornmann, W.; Kantarjian, H.; Viallet, J.; Samudio, I.; et al. Mechanisms of antileukemic activity of the novel bcl-2 homology domain-3 mimetic GX15-070 (obatoclax). Cancer Res. 2008, 68, 3413-3420. [CrossRef] [PubMed]

106. Pan, J.; Cheng, C.; Verstovsek, S.; Chen, Q.; Jin, Y.; Cao, Q. The BH3-mimetic GX15-070 induces autophagy, potentiates the cytotoxicity of carboplatin and 5-fluorouracil in esophageal carcinoma cells. Cancer Lett. 2010, 293, 167-174. [CrossRef]

107. Joudeh, J.; Claxton, D. Obatoclax mesylate : Pharmacology and potential for therapy of hematological neoplasms. Expert Opin. Investig. Drugs 2012, 21, 363-373. [CrossRef] [PubMed]

108. Hwang, J.J.; Kuruvilla, J.; Mendelson, D.; Pishvaian, M.J.; Deeken, J.F.; Siu, L.L.; Berger, M.S.; Viallet, J.; Marshall, J.L. Phase I dose finding studies of obatoclax (GX15-070), a small molecule pan-bcl-2 family antagonist, in patients with advanced solid tumors or lymphoma. Clin. Cancer Res. 2010, 16, 4038-4045. [CrossRef] [PubMed]

109. Hughes, C.C.; Prieto-Davo, A.; Jensen, P.R.; Fenical, W. The marinopyrroles, antibiotics of an unprecedented structure class from a marine Streptomyces sp. Org. Lett. 2008, 10, 629-631. [CrossRef] [PubMed]

110. Doi, K.; Liu, Q.; Gowda, K.; Barth, B.M.; Claxton, D.; Amin, S.; Loughran, T.P., Jr.; Wang, H.G. Maritoclax induces apoptosis in acute myeloid leukemia cells with elevated mcl-1 expression. Cancer Biol. Ther. 2014, 15. [CrossRef] [PubMed]

111. Wei, J.; Kitada, S.; Stebbins, J.L.; Placzek, W.; Zhai, D.; Wu, B.; Rega, M.F.; Zhang, Z.; Cellitti, J.; Yang, L.; et al. Synthesis and biological evaluation of apogossypolone derivatives as pan-active inhibitors of antiapoptotic B-cell lymphoma/leukemia-2 (bcl-2) family proteins. J. Med. Chem. 2010, 53, 8000-8011. [CrossRef] [PubMed]

112. Baggstrom, M.Q.; Qi, Y.; Koczywas, M.; Argiris, A.; Johnson, E.A.; Millward, M.J.; Murphy, S.C.; Erlichman, C.; Rudin, C.M.; Govindan, R. A phase II study of AT-101 (gossypol) in chemotherapy-sensitive recurrent extensive-stage small cell lung cancer. J. Thorac. Oncol. 2011, 6, 1757-1760. [CrossRef] [PubMed]

113. Wang, Z.; Song, W.; Aboukameel, A.; Mohammad, M.; Wang, G.; Banerjee, S.; Kong, D.; Wang, S.; Sarkar, F.H.; Mohammad, R.M. Tw-37, a small-molecule inhibitor of bcl-2, inhibits cell growth and invasion in pancreatic cancer. Int. J. Cancer 2008, 123, 958-966. [CrossRef] [PubMed]

114. Mohammad, R.M.; Goustin, A.S.; Aboukameel, A.; Chen, B.; Banerjee, S.; Wang, G.; Nikolovska-Coleska, Z.; Wang, S.; Al-Katib, A. Preclinical studies of TW-37, a new nonpeptidic small-molecule inhibitor of bcl-2, in diffuse large cell lymphoma xenograft model reveal drug action on both bcl-2 and mcl-1. Clin. Cancer Res. 2007, 13, 2226-2235. [CrossRef] [PubMed]

115. Zeitlin, B.D.; Joo, E.; Dong, Z.; Warner, K.; Wang, G.; Nikolovska-Coleska, Z.; Wang, S.; Nor, J.E. Antiangiogenic effect of TW37, a small-molecule inhibitor of bcl-2. Cancer Res. 2006, 66, 8698-8706. [CrossRef] [PubMed]

116. Sun, J.; Li, Z.M.; Hu, Z.Y.; Zeng, Z.L.; Yang, D.J.; Jiang, W.Q. Apogossypolone inhibits cell growth by inducing cell cycle arrest in u937 cells. Oncol. Rep. 2009, 22, 193-198. [PubMed]

117. Paoluzzi, L.; Gonen, M.; Gardner, J.R.; Mastrella, J.; Yang, D.; Holmlund, J.; Sorensen, M.; Leopold, L.; Manova, K.; Marcucci, G.; et al. Targeting bcl-2 family members with the BH3 mimetic AT-101 markedly enhances the therapeutic effects of chemotherapeutic agents in in vitro and in vivo models of b-cell lymphoma. Blood 2008, 111, 5350-5358. [CrossRef] [PubMed] 
118. Wei, J.; Stebbins, J.L.; Kitada, S.; Dash, R.; Placzek, W.; Rega, M.F.; Wu, B.; Cellitti, J.; Zhai, D.; Yang, L.; et al. BI-97C1, an optically pure apogossypol derivative as pan-active inhibitor of antiapoptotic B-cell lymphoma/leukemia-2 (bcl-2) family proteins. J. Med. Chem. 2010, 53, 4166-4176. [CrossRef] [PubMed]

119. Dash, R.; Azab, B.; Quinn, B.A.; Shen, X.; Wang, X.Y.; Das, S.K.; Rahmani, M.; Wei, J.; Hedvat, M.; Dent, P.; et al. Apogossypol derivative BI-97C1 (Sabutoclax) targeting mcl-1 sensitizes prostate cancer cells to mda-7/IL-24-mediated toxicity. Proc. Natl. Acad. Sci. USA 2011, 108, 8785-8790. [CrossRef] [PubMed]

120. Kazi, A.; Sun, J.; Doi, K.; Sung, S.S.; Takahashi, Y.; Yin, H.; Rodriguez, J.M.; Becerril, J.; Berndt, N.; Hamilton, A.D.; et al. The BH3 $\alpha$-helical mimic BH3-m6 disrupts bcl-x(l), bcl-2, and mcl-1 protein-protein interactions with bax, bak, bad, or bim and induces apoptosis in a bax- and bim-dependent manner. J. Biol. Chem. 2011, 286, 9382-9392. [CrossRef] [PubMed]

121. Varfolomeev, E.; Blankenship, J.W.; Wayson, S.M.; Fedorova, A.V.; Kayagaki, N.; Garg, P.; Zobel, K.; Dynek, J.N.; Elliott, L.O.; Wallweber, H.J.; et al. IAP antagonists induce autoubiquitination of c-IAPs, NF- $k b$ activation, and TNF $\alpha$-dependent apoptosis. Cell 2007, 131, 669-681. [CrossRef] [PubMed]

122. Vince, J.E.; Wong, W.W.; Khan, N.; Feltham, R.; Chau, D.; Ahmed, A.U.; Benetatos, C.A.; Chunduru, S.K.; Condon, S.M.; McKinlay, M.; et al. IAP antagonists target ciap1 to induce TNF $\alpha$-dependent apoptosis. Cell 2007, 131, 682-693. [CrossRef] [PubMed]

123. Ndubaku, C.; Varfolomeev, E.; Wang, L.; Zobel, K.; Lau, K.; Elliott, L.O.; Maurer, B.; Fedorova, A.V.; Dynek, J.N.; Koehler, M.; et al. Antagonism of c-IAP and XIAP proteins is required for efficient induction of cell death by small-molecule IAP antagonists. ACS Chem. Biol. 2009, 4, 557-566. [CrossRef] [PubMed]

124. Schimmer, A.D.; Dalili, S.; Batey, R.A.; Riedl, S.J. Targeting XIAP for the treatment of malignancy. Cell Death Differ. 2006, 13, 179-188. [CrossRef] [PubMed]

125. Li, L.; Thomas, R.M.; Suzuki, H.; De Brabander, J.K.; Wang, X.; Harran, P.G. A small molecule smac mimic potentiates trail- and TNF $\alpha$-mediated cell death. Science 2004, 305, 1471-1474. [CrossRef] [PubMed]

126. Ndubaku, C.; Cohen, F.; Varfolomeev, E.; Vucic, D. Targeting inhibitor of apoptosis proteins for therapeutic intervention. Future Med. Chem. 2009, 1, 1509-1525. [CrossRef] [PubMed]

127. Sun, H.; Nikolovska-Coleska, Z.; Lu, J.; Meagher, J.L.; Yang, C.Y.; Qiu, S.; Tomita, Y.; Ueda, Y.; Jiang, S.; Krajewski, K.; et al. Design, synthesis, and characterization of a potent, nonpeptide, cell-permeable, bivalent smac mimetic that concurrently targets both the BIR2 and BIR3 domains in XIAP. J. Am. Chem. Soc. 2007, 129, 15279-15294. [CrossRef] [PubMed]

128. Petersen, S.L.; Wang, L.; Yalcin-Chin, A.; Li, L.; Peyton, M.; Minna, J.; Harran, P.; Wang, X. Autocrine TNF $\alpha$ signaling renders human cancer cells susceptible to Smac-mimetic-induced apoptosis. Cancer Cell 2007, 12, 445-456. [CrossRef] [PubMed]

129. Chai, J.; Du, C.; Wu, J.W.; Kyin, S.; Wang, X.; Shi, Y. Structural and biochemical basis of apoptotic activation by Smac/DIABLO. Nature 2000, 406, 855-862. [PubMed]

130. Verhagen, A.M.; Ekert, P.G.; Pakusch, M.; Silke, J.; Connolly, L.M.; Reid, G.E.; Moritz, R.L.; Simpson, R.J.; Vaux, D.L. Identification of DIABLO, a mammalian protein that promotes apoptosis by binding to and antagonizing IAP proteins. Cell 2000, 102, 43-53. [CrossRef]

131. Wu, G.; Chai, J.; Suber, T.L.; Wu, J.W.; Du, C.; Wang, X.; Shi, Y. Structural basis of IAP recognition by Smac/DIABLO. Nature 2000, 408, 1008-1012. [PubMed]

132. Franklin, M.C.; Kadkhodayan, S.; Ackerly, H.; Alexandru, D.; Distefano, M.D.; Elliott, L.O.; Flygare, J.A.; Mausisa, G.; Okawa, D.C.; Ong, D.; et al. Structure and function analysis of peptide antagonists of melanoma inhibitor of apoptosis (ML-IAP). Biochemistry 2003, 42, 8223-8231. [CrossRef] [PubMed]

133. Vucic, D.; Deshayes, K.; Ackerly, H.; Pisabarro, M.T.; Kadkhodayan, S.; Fairbrother, W.J.; Dixit, V.M. Smac negatively regulates the anti-apoptotic activity of melanoma inhibitor of apoptosis (ML-IAP). J. Biol. Chem. 2002, 277, 12275-12279. [CrossRef] [PubMed]

134. Fulda, S.; Wick, W.; Weller, M.; Debatin, K.M. Smac agonists sensitize for APO2L/trail- or anticancer drug-induced apoptosis and induce regression of malignant glioma in vivo. Nat. Med. 2002, 8, 808-815. [CrossRef] [PubMed]

135. Schulte, T.W.; Neckers, L.M. The benzoquinone ansamycin 17-allylamino-17-demethoxygeldanamycin binds to hsp90 and shares important biologic activities with geldanamycin. Cancer Chemother. Pharmacol. 1998, 42, 273-279. [CrossRef] [PubMed]

136. Kim, Y.S.; Alarcon, S.V.; Lee, S.; Lee, M.J.; Giaccone, G.; Neckers, L.; Trepel, J.B. Update on hsp90 inhibitors in clinical trial. Curr. Top. Med. Chem. 2009, 9, 1479-1492. [CrossRef] [PubMed] 
137. Sydor, J.R.; Normant, E.; Pien, C.S.; Porter, J.R.; Ge, J.; Grenier, L.; Pak, R.H.; Ali, J.A.; Dembski, M.S.; Hudak, J.; et al. Development of 17-allylamino-17-demethoxygeldanamycin hydroquinone hydrochloride (IPI-504), an anti-cancer agent directed against hsp90. Proc. Natl. Acad. Sci. USA 2006, 103, 17408-17413. [CrossRef] [PubMed]

138. Ge, J.; Normant, E.; Porter, J.R.; Ali, J.A.; Dembski, M.S.; Gao, Y.; Georges, A.T.; Grenier, L.; Pak, R.H.; Patterson, J.; et al. Design, synthesis, and biological evaluation of hydroquinone derivatives of 17-amino-17-demethoxygeldanamycin as potent, water-soluble inhibitors of hsp90. J. Med. Chem. 2006, 49, 4606-4615. [CrossRef] [PubMed]

139. Yang, Z.Q.; Geng, X.; Solit, D.; Pratilas, C.A.; Rosen, N.; Danishefsky, S.J. New efficient synthesis of resorcinylic macrolides via ynolides: Establishment of cycloproparadicicol as synthetically feasible preclinical anticancer agent based on hsp90 as the target. J. Am. Chem. Soc. 2004, 126, 7881-7889. [CrossRef] [PubMed]

140. Jhaveri, K.; Taldone, T.; Modi, S.; Chiosis, G. Advances in the clinical development of heat shock protein 90 (hsp90) inhibitors in cancers. Biochim. Biophys. Acta 2012, 1823, 742-755. [CrossRef] [PubMed]

141. Chiosis, G.; Timaul, M.N.; Lucas, B.; Munster, P.N.; Zheng, F.F.; Sepp-Lorenzino, L.; Rosen, N. A small molecule designed to bind to the adenine nucleotide pocket of hsp90 causes her2 degradation and the growth arrest and differentiation of breast cancer cells. Chem. Biol. 2001, 8, 289-299. [CrossRef]

142. Caldas-Lopes, E.; Cerchietti, L.; Ahn, J.H.; Clement, C.C.; Robles, A.I.; Rodina, A.; Moulick, K.; Taldone, T.; Gozman, A.; Guo, Y.; et al. Hsp90 inhibitor PU-H71, a multimodal inhibitor of malignancy, induces complete responses in triple-negative breast cancer models. Proc. Natl. Acad. Sci. USA 2009, 106, 8368-8373. [CrossRef] [PubMed]

143. Kasibhatla, S.R.; Hong, K.; Biamonte, M.A.; Busch, D.J.; Karjian, P.L.; Sensintaffar, J.L.; Kamal, A.; Lough, R.E.; Brekken, J.; Lundgren, K.; et al. Rationally designed high-affinity 2-amino-6-halopurine heat shock protein 90 inhibitors that exhibit potent antitumor activity. J. Med. Chem. 2007, 50, 2767-2778. [CrossRef] [PubMed]

144. Bao, R.; Lai, C.J.; Qu, H.; Wang, D.; Yin, L.; Zifcak, B.; Atoyan, R.; Wang, J.; Samson, M.; Forrester, J.; et al. CUDC-305, a novel synthetic HSP90 inhibitor with unique pharmacologic properties for cancer therapy. Clin. Cancer Res. 2009, 15, 4046-4057. [CrossRef] [PubMed]

145. Lundgren, K.; Zhang, H.; Brekken, J.; Huser, N.; Powell, R.E.; Timple, N.; Busch, D.J.; Neely, L.; Sensintaffar, J.L.; Yang, Y.C.; et al. BIIB021, an orally available, fully synthetic small-molecule inhibitor of the heat shock protein hsp90. Mol. Cancer Ther. 2009, 8, 921-929. [CrossRef] [PubMed]

146. Aggarwal, B.B.; Van Kuiken, M.E.; Iyer, L.H.; Harikumar, K.B.; Sung, B. Molecular targets of nutraceuticals derived from dietary spices: Potential role in suppression of inflammation and tumorigenesis. Exp. Biol. Med. 2009, 234, 825-849. [CrossRef] [PubMed]

147. Dhillon, N.; Aggarwal, B.B.; Newman, R.A.; Wolff, R.A.; Kunnumakkara, A.B.; Abbruzzese, J.L.; Ng, C.S.; Badmaev, V.; Kurzrock, R. Phase II trial of curcumin in patients with advanced pancreatic cancer. Clin. Cancer Res. 2008, 14, 4491-4499. [CrossRef] [PubMed]

148. Sonpavde, G.; Matveev, V.; Burke, J.M.; Caton, J.R.; Fleming, M.T.; Hutson, T.E.; Galsky, M.D.; Berry, W.R.; Karlov, P.; Holmlund, J.T.; et al. Randomized phase II trial of docetaxel plus prednisone in combination with placebo or AT-101, an oral small molecule bcl-2 family antagonist, as first-line therapy for metastatic castration-resistant prostate cancer. Ann. Oncol. 2012, 23, 1803-1808. [CrossRef] [PubMed]

149. Liu, B.; Bai, Q.X.; Chen, X.Q.; Gao, G.X.; Gu, H.T. Effect of curcumin on expression of survivin, bcl-2 and bax in human multiple myeloma cell line. Zhongguo Shi Yan Xue Ye Xue Za Zhi 2007, 15, 762-766. [PubMed]

150. Kolettas, E.; Thomas, C.; Leneti, E.; Skoufos, I.; Mbatsi, C.; Sisoula, C.; Manos, G.; Evangelou, A. Rosmarinic acid failed to suppress hydrogen peroxide-mediated apoptosis but induced apoptosis of jurkat cells which was suppressed by bcl-2. Mol. Cell. Biochem. 2006, 285, 111-120. [CrossRef] [PubMed]

151. Ahmed, N.; Laverick, L.; Sammons, J.; Zhang, H.; Maslin, D.J.; Hassan, H.T. Ajoene, a garlic-derived natural compound, enhances chemotherapy-induced apoptosis in human myeloid leukaemia CD34-positive resistant cells. Anticancer Res. 2001, 21, 3519-3523. [PubMed]

152. Goy, A.; Hernandez-Ilzaliturri, F.J.; Kahl, B.; Ford, P.; Protomastro, E.; Berger, M. A phase I/II study of the pan bcl-2 inhibitor obatoclax mesylate plus bortezomib for relapsed or refractory mantle cell lymphoma. Leuk. Lymphoma 2014, 55, 2761-2768. [CrossRef] [PubMed] 
153. Wiechno, P.; Somer, B.G.; Mellado, B.; Chlosta, P.L.; Cervera Grau, J.M.; Castellano, D.; Reuter, C.; Stockle, M.; Kamradt, J.; Pikiel, J.; et al. A randomised phase 2 study combining ly2181308 sodium (survivin antisense oligonucleotide) with first-line docetaxel/prednisone in patients with castration-resistant prostate cancer. Eur. Urol. 2014, 65, 516-520. [CrossRef] [PubMed]

154. Sinicrope, F.A.; Penington, R.C.; Tang, X.M. Tumor necrosis factor-related apoptosis-inducing ligand-induced apoptosis is inhibited by bcl-2 but restored by the small molecule bcl-2 inhibitor, HA 14-1, in human colon cancer cells. Clin. Cancer Res. 2004, 10, 8284-8292. [CrossRef] [PubMed]

155. Mesri, M.; Wall, N.R.; Li, J.; Kim, R.W.; Altieri, D.C. Cancer gene therapy using a survivin mutant adenovirus. J. Clin. Investig. 2001, 108, 981-990. [CrossRef] [PubMed]

156. Arisan, E.D.; Kutuk, O.; Tezil, T.; Bodur, C.; Telci, D.; Basaga, H. Small inhibitor of bcl-2, HA14-1, selectively enhanced the apoptotic effect of cisplatin by modulating bcl-2 family members in MDA-MB-231 breast cancer cells. Breast Cancer Res. Treat. 2010, 119, 271-281. [CrossRef] [PubMed]

157. Raetz, E.A.; Morrison, D.; Romanos-Sirakis, E.; Gaynon, P.; Sposto, R.; Bhojwani, D.; Bostrom, B.C.; Brown, P.; Eckroth, E.; Cassar, J.; et al. A phase I study of EZN-3042, a novel survivin messenger ribonucleic acid (mRNA) antagonist, administered in combination with chemotherapy in children with relapsed acute lymphoblastic leukemia (ALL): A report from the therapeutic advances in childhood leukemia and lymphoma (TACL) consortium. J. Pediatr. Hematol. Oncol. 2013. [CrossRef]

158. Mitsiades, C.S.; Hayden, P.; Kotoula, V.; McMillin, D.W.; McMullan, C.; Negri, J.; Delmore, J.E.; Poulaki, V.; Mitsiades, N. Bcl-2 overexpression in thyroid carcinoma cells increases sensitivity to bcl-2 homology 3 domain inhibition. J. Clin. Endocrinol. Metab. 2007, 92, 4845-4852. [CrossRef] [PubMed]

159. Hansen, J.B.; Fisker, N.; Westergaard, M.; Kjaerulff, L.S.; Hansen, H.F.; Thrue, C.A.; Rosenbohm, C.; Wissenbach, M.; Orum, H.; Koch, T. Spc3042: A proapoptotic survivin inhibitor. Mol. Cancer Ther. 2008, 7, 2736-2745. [CrossRef] [PubMed]

160. Al-Karaawi, M.A. Interaction studies to evaluate 2-carboxyphenolate analogues as inhibitor of anti-apoptotic protein bcl-2. Bioinformation 2013, 9, 477-480. [CrossRef] [PubMed]

161. Kelly, R.J.; Thomas, A.; Rajan, A.; Chun, G.; Lopez-Chavez, A.; Szabo, E.; Spencer, S.; Carter, C.A.; Guha, U.; Khozin, S.; et al. A phase I/II study of sepantronium bromide (YM155, survivin suppressor) with paclitaxel and carboplatin in patients with advanced non-small-cell lung cancer. Ann. Oncol. 2013, 24, 2601-2606. [CrossRef] [PubMed]

162. Felix, S.; Sandjo, L.P.; Opatz, T.; Erkel, G. SF002-96-1, a new drimane sesquiterpene lactone from an aspergillus species, inhibits survivin expression. Beilstein J. Org. Chem. 2013, 9, 2866-2876. [CrossRef] [PubMed]

163. Shanafelt, T.D.; Call, T.G.; Zent, C.S.; Leis, J.F.; LaPlant, B.; Bowen, D.A.; Roos, M.; Laumann, K.; Ghosh, A.K.; Lesnick, C.; et al. Phase 2 trial of daily, oral polyphenon e in patients with asymptomatic, RAI stage 0 to II chronic lymphocytic leukemia. Cancer 2013, 119, 363-370. [CrossRef] [PubMed]

164. Wadegaonkar, V.P.; Wadegaonkar, P.A. Withanone as an inhibitor of survivin: A potential drug candidate for cancer therapy. J. Biotechnol. 2013, 168, 229-233. [CrossRef] [PubMed]

165. Lee, S.; Braun, C.R.; Bird, G.H.; Walensky, L.D. Photoreactive stapled peptides to identify and characterize bcl-2 family interaction sites by mass spectrometry. Methods Enzymol. 2014, 544, 25-48. [PubMed]

166. Shi, X.; Wang, D.; Ding, K.; Lu, Z.; Jin, Y.; Zhang, J.; Pan, J. GDP366, a novel small molecule dual inhibitor of survivin and Op18, induces cell growth inhibition, cellular senescence and mitotic catastrophe in human cancer cells. Cancer Biol. Ther. 2010, 9, 640-650. [CrossRef] [PubMed]

167. Real, P.J.; Cao, Y.; Wang, R.; Nikolovska-Coleska, Z.; Sanz-Ortiz, J.; Wang, S.; Fernandez-Luna, J.L. Breast cancer cells can evade apoptosis-mediated selective killing by a novel small molecule inhibitor of bcl-2. Cancer Res. 2004, 64, 7947-7953. [CrossRef] [PubMed]

168. Kaneko, M.; Nakashima, T.; Uosaki, Y.; Hara, M.; Ikeda, S.; Kanda, Y. Synthesis of tetrocarcin derivatives with specific inhibitory activity towards bcl-2 functions. Bioorg. Med. Chem. Lett. 2001, 11, 887-890. [CrossRef]

169. Chan, S.L.; Lee, M.C.; Tan, K.O.; Yang, L.K.; Lee, A.S.; Flotow, H.; Fu, N.Y.; Butler, M.S.; Soejarto, D.D.; Buss, A.D.; et al. Identification of chelerythrine as an inhibitor of bclxl function. J. Biol. Chem. 2003, 278, 20453-20456. [CrossRef] [PubMed]

170. Varadarajan, S.; Vogler, M.; Butterworth, M.; Dinsdale, D.; Walensky, L.D.; Cohen, G.M. Evaluation and critical assessment of putative mcl-1 inhibitors. Cell Death Differ. 2013, 20, 1475-1484. [CrossRef] [PubMed] 
171. Lessene, G.; Czabotar, P.E.; Sleebs, B.E.; Zobel, K.; Lowes, K.N.; Adams, J.M.; Baell, J.B.; Colman, P.M.; Deshayes, K.; Fairbrother, W.J.; et al. Structure-guided design of a selective bcl-x(l) inhibitor. Nat. Chem. Biol. 2013, 9, 390-397. [CrossRef] [PubMed]

172. Wang, Z.; Goulet, R., 3rd; Stanton, K.J.; Sadaria, M.; Nakshatri, H. Differential effect of anti-apoptotic genes bcl-xl and c-flip on sensitivity of mcf-7 breast cancer cells to paclitaxel and docetaxel. Anticancer Res. 2005, 25, 2367-2379. [PubMed]

173. Wu, T.Y.; Wagner, K.W.; Bursulaya, B.; Schultz, P.G.; Deveraux, Q.L. Development and characterization of nonpeptidic small molecule inhibitors of the xiap/caspase-3 interaction. Chem. Biol. 2003, 10, 759-767. [CrossRef]

174. Bai, L.; Chen, J.; McEachern, D.; Liu, L.; Zhou, H.; Aguilar, A.; Wang, S. BM-1197: A novel and specific bcl-2/bcl-xl inhibitor inducing complete and long-lasting tumor regression in vivo. PLoS ONE 2014, 9. [CrossRef] [PubMed]

175. Aguilar, A.; Zhou, H.; Chen, J.; Liu, L.; Bai, L.; McEachern, D.; Yang, C.Y.; Meagher, J.; Stuckey, J.; Wang, S. A potent and highly efficacious bcl-2/bcl-xl inhibitor. J. Med. Chem. 2013, 56, 3048-3067. [CrossRef] [PubMed]

176. Ling, X.; Cao, S.; Cheng, Q.; Keefe, J.T.; Rustum, Y.M.; Li, F. A novel small molecule FL118 that selectively inhibits survivin, mcl-1, XIAP and cIAP2 in a p53-independent manner, shows superior antitumor activity. PLoS ONE 2012, 7. [CrossRef] [PubMed]

177. Melkko, S.; Mannocci, L.; Dumelin, C.E.; Villa, A.; Sommavilla, R.; Zhang, Y.; Grutter, M.G.; Keller, N.; Jermutus, L.; Jackson, R.H.; et al. Isolation of a small-molecule inhibitor of the antiapoptotic protein bcl-xl from a DNA-encoded chemical library. ChemMedChem 2010, 5, 584-590. [CrossRef] [PubMed]

178. Lin, J.; Zheng, Z.; Li, Y.; Yu, W.; Zhong, W.; Tian, S.; Zhao, F.; Ren, X.; Xiao, J.; Wang, N.; et al. A novel bcl-xl inhibitor z36 that induces autophagic cell death in hela cells. Autophagy 2009, 5, 314-320. [CrossRef] [PubMed]

179. Wang, S.; Wang, X.; Du, Z.; Liu, Y.; Huang, D.; Zheng, K.; Liu, K.; Zhang, Y.; Zhong, X.; Wang, Y. SNX-25a, a novel hsp90 inhibitor, inhibited human cancer growth more potently than 17-AAG. Biochem. Biophys. Res. Commun. 2014, 450, 73-80. [CrossRef] [PubMed]

180. Ponassi, R.; Biasotti, B.; Tomati, V.; Bruno, S.; Poggi, A.; Malacarne, D.; Cimoli, G.; Salis, A.; Pozzi, S.; Miglino, M.; et al. A novel Bim-BH3-derived bcl-XL inhibitor: Biochemical characterization, in vitro, in vivo and ex-vivo anti-leukemic activity. Cell Cycle 2008, 7, 3211-3224. [CrossRef] [PubMed]

181. Burlison, J.A.; Neckers, L.; Smith, A.B.; Maxwell, A.; Blagg, B.S. Novobiocin: Redesigning a DNA gyrase inhibitor for selective inhibition of hsp90. J. Am. Chem. Soc. 2006, 128, 15529-15536. [CrossRef] [PubMed]

182. Shoemaker, A.R.; Oleksijew, A.; Bauch, J.; Belli, B.A.; Borre, T.; Bruncko, M.; Deckwirth, T.; Frost, D.J.; Jarvis, K.; Joseph, M.K.; et al. A small-molecule inhibitor of bcl-XL potentiates the activity of cytotoxic drugs in vitro and in vivo. Cancer Res. 2006, 66, 8731-8739. [CrossRef] [PubMed]

183. Zhao, Q.; Wu, C.Z.; Lee, J.K.; Zhao, S.R.; Li, H.M.; Huo, Q.; Ma, T.; Zhang, J.; Hong, Y.S.; Liu, H. Anticancer effects of the hsp90 inhibitor 17-demethoxy-reblastatin in human breast cancer MDA-MB-231 cells. J. Microbiol. Biotechnol. 2014, 24, 914-920. [PubMed]

184. Broome, H.E.; Yu, A.L.; Diccianni, M.; Camitta, B.M.; Monia, B.P.; Dean, N.M. Inhibition of bcl-xl expression sensitizes t-cell acute lymphoblastic leukemia cells to chemotherapeutic drugs. Leuk. Res. 2002, 26, 311-316. [CrossRef]

185. Stenderup, K.; Rosada, C.; Gavillet, B.; Vuagniaux, G.; Dam, T.N. DEBIO 0932, a new oral hsp90 inhibitor, alleviates psoriasis in a xenograft transplantation model. Acta Derm. Venereol. 2014, 94, 672-676. [CrossRef] [PubMed]

186. Wacheck, V.; Selzer, E.; Gunsberg, P.; Lucas, T.; Meyer, H.; Thallinger, C.; Monia, B.P.; Jansen, B. Bcl-x(l) antisense oligonucleotides radiosensitise colon cancer cells. Br. J. Cancer 2003, 89, 1352-1357. [CrossRef] [PubMed]

187. Chandarlapaty, S.; Sawai, A.; Ye, Q.; Scott, A.; Silinski, M.; Huang, K.; Fadden, P.; Partdrige, J.; Hall, S.; Steed, P.; et al. SNX2112, a synthetic heat shock protein 90 inhibitor, has potent antitumor activity against her kinase-dependent cancers. Clin. Cancer Res. 2008, 14, 240-248. [CrossRef] [PubMed]

188. Yin, H.; Lee, G.I.; Sedey, K.A.; Kutzki, O.; Park, H.S.; Orner, B.P.; Ernst, J.T.; Wang, H.G.; Sebti, S.M.; Hamilton, A.D. Terphenyl-based Bak BH3 $\alpha$-helical proteomimetics as low-molecular-weight antagonists of bcl-xl. J. Am. Chem. Soc. 2005, 127, 10191-10196. [CrossRef] [PubMed] 
189. Fotsop, D.F.; Roussi, F.; Leverrier, A.; Breteche, A.; Gueritte, F. Biomimetic total synthesis of meiogynin a, an inhibitor of bcl-xl and bak interaction. J. Org. Chem. 2010, 75, 7412-7415. [CrossRef] [PubMed]

190. Woodhead, A.J.; Angove, H.; Carr, M.G.; Chessari, G.; Congreve, M.; Coyle, J.E.; Cosme, J.; Graham, B.; Day, P.J.; Downham, R.; et al. Discovery of (2,4-dihydroxy-5-isopropylphenyl)-[5-(4-methylpiperazin -1-ylmethyl)-1,3-dihydrois oindol-2-yl]methanone (AT13387), a novel inhibitor of the molecular chaperone hsp90 by fragment based drug design. J. Med. Chem. 2010, 53, 5956-5969. [CrossRef] [PubMed]

191. Fogliatto, G.; Gianellini, L.; Brasca, M.G.; Casale, E.; Ballinari, D.; Ciomei, M.; Degrassi, A.; De Ponti, A.; Germani, M.; Guanci, M.; et al. NMS-E973, a novel synthetic inhibitor of hsp90 with activity against multiple models of drug resistance to targeted agents, including intracranial metastases. Clin. Cancer Res. 2013, 19, 3520-3532. [CrossRef] [PubMed]

192. Rudin, C.M.; Hann, C.L.; Garon, E.B.; Ribeiro de Oliveira, M.; Bonomi, P.D.; Camidge, D.R.; Chu, Q.; Giaccone, G.; Khaira, D.; Ramalingam, S.S.; et al. Phase II study of single-agent navitoclax (ABT-263) and biomarker correlates in patients with relapsed small cell lung cancer. Clin. Cancer Res. 2012, 18, 3163-3169. [CrossRef] [PubMed]

193. Bhat, R.; Tummalapalli, S.R.; Rotella, D.P. Progress in the discovery and development of heat shock protein 90 (hsp90) inhibitors. J. Med. Chem. 2014, 57, 8718-8728. [CrossRef] [PubMed]

194. Souers, A.J.; Leverson, J.D.; Boghaert, E.R.; Ackler, S.L.; Catron, N.D.; Chen, J.; Dayton, B.D.; Ding, H.; Enschede, S.H.; Fairbrother, W.J.; et al. ABT-199, a potent and selective bcl-2 inhibitor, achieves antitumor activity while sparing platelets. Nat. Med. 2013, 19, 202-208. [CrossRef] [PubMed]

195. Vassallo, A.; Vaccaro, M.C.; De Tommasi, N.; Dal Piaz, F.; Leone, A. Identification of the plant compound geraniin as a novel hsp90 inhibitor. PLoS ONE 2013, 8. [CrossRef]

196. Ono, N.; Yamazaki, T.; Nakanishi, Y.; Fujii, T.; Sakata, K.; Tachibana, Y.; Suda, A.; Hada, K.; Miura, T.; Sato, S.; et al. Preclinical antitumor activity of the novel heat shock protein 90 inhibitor CH5164840 against human epidermal growth factor receptor 2 (HER2)-overexpressing cancers. Cancer Sci. 2012, 103, 342-349. [CrossRef] [PubMed]

197. Chen, J.; Zhou, H.; Aguilar, A.; Liu, L.; Bai, L.; McEachern, D.; Yang, C.Y.; Meagher, J.L.; Stuckey, J.A.; Wang, S. Structure-based discovery of BM-957 as a potent small-molecule inhibitor of bcl-2 and bcl-xl capable of achieving complete tumor regression. J. Med. Chem. 2012, 55, 8502-8514. [CrossRef] [PubMed]

198. Khandelwal, A.; Hall, J.A.; Blagg, B.S. Synthesis and structure-activity relationships of EGCG analogues, a recently identified hsp90 inhibitor. J. Org. Chem. 2013, 78, 7859-7884. [CrossRef] [PubMed]

199. Chauhan, D.; Velankar, M.; Brahmandam, M.; Hideshima, T.; Podar, K.; Richardson, P.; Schlossman, R.; Ghobrial, I.; Raje, N.; Munshi, N.; et al. A novel bcl-2/bcl-x(l)/bcl-w inhibitor ABT-737 as therapy in multiple myeloma. Oncogene 2007, 26, 2374-2380. [CrossRef] [PubMed]

200. Margarucci, L.; Monti, M.C.; Cassiano, C.; Mozzicafreddo, M.; Angeletti, M.; Riccio, R.; Tosco, A.; Casapullo, A. Chemical proteomics-driven discovery of oleocanthal as an hsp90 inhibitor. Chem. Commun. 2013, 49, 5844-5846. [CrossRef]

201. Lyman, S.K.; Crawley, S.C.; Gong, R.; Adamkewicz, J.I.; McGrath, G.; Chew, J.Y.; Choi, J.; Holst, C.R.; Goon, L.H.; Detmer, S.A.; et al. High-content, high-throughput analysis of cell cycle perturbations induced by the hsp90 inhibitor xl888. PLoS ONE 2011, 6. [CrossRef]

202. Best, O.G.; Singh, N.; Forsyth, C.; Mulligan, S.P. The novel hsp-90 inhibitor SNX7081 is significantly more potent than 17-AAG against primary cll cells and a range of haematological cell lines, irrespective of lesions in the tp53 pathway. Br. J. Haematol. 2010, 151, 185-188. [CrossRef] [PubMed]

203. Menezes, D.L.; Taverna, P.; Jensen, M.R.; Abrams, T.; Stuart, D.; Yu, G.K.; Duhl, D.; Machajewski, T.; Sellers, W.R.; Pryer, N.K.; et al. The novel oral hsp90 inhibitor NVP-HSP990 exhibits potent and broad-spectrum antitumor activities in vitro and in vivo. Mol. Cancer Ther. 2012, 11, 730-739. [CrossRef] [PubMed]

204. He, Y.; Li, Y.; Zhang, S.; Perry, B.; Zhao, T.; Wang, Y.; Sun, C. Radicicol, a heat shock protein 90 inhibitor, inhibits differentiation and adipogenesis in 3T3-L1 preadipocytes. Biochem. Biophys. Res. Commun. 2013, 436, 169-174. [CrossRef] [PubMed]

205. Oost, T.K.; Sun, C.; Armstrong, R.C.; Al-Assaad, A.S.; Betz, S.F.; Deckwerth, T.L.; Ding, H.; Elmore, S.W.; Meadows, R.P.; Olejniczak, E.T.; et al. Discovery of potent antagonists of the antiapoptotic protein xiap for the treatment of cancer. J. Med. Chem. 2004, 47, 4417-4426. [CrossRef] [PubMed] 
206. Liston, P.; Fong, W.G.; Kelly, N.L.; Toji, S.; Miyazaki, T.; Conte, D.; Tamai, K.; Craig, C.G.; McBurney, M.W.; Korneluk, R.G. Identification of XAF1 as an antagonist of xiap anti-caspase activity. Nat. Cell Biol. 2001, 3, 128-133. [CrossRef] [PubMed]

207. Ju, H.Q.; Xiang, Y.F.; Xin, B.J.; Pei, Y.; Lu, J.X.; Wang, Q.L.; Xia, M.; Qian, C.W.; Ren, Z.; Wang, S.Y.; et al. Synthesis and in vitro anti-HSV-1 activity of a novel hsp90 inhibitor BJ-B11. Bioorg. Med. Chem. Lett. 2011, 21, 1675-1677. [CrossRef] [PubMed]

208. Schimmer, A.D.; Welsh, K.; Pinilla, C.; Wang, Z.; Krajewska, M.; Bonneau, M.J.; Pedersen, I.M.; Kitada, S.; Scott, F.L.; Bailly-Maitre, B.; et al. Small-molecule antagonists of apoptosis suppressor XIAP exhibit broad antitumor activity. Cancer Cell 2004, 5, 25-35. [CrossRef]

209. Nakashima, T.; Ishii, T.; Tagaya, H.; Seike, T.; Nakagawa, H.; Kanda, Y.; Akinaga, S.; Soga, S.; Shiotsu, Y. New molecular and biological mechanism of antitumor activities of KW-2478, a novel nonansamycin heat shock protein 90 inhibitor, in multiple myeloma cells. Clin. Cancer Res. 2010, 16, 2792-2802. [CrossRef] [PubMed]

210. Kim, S.H.; Bajji, A.; Tangallapally, R.; Markovitz, B.; Trovato, R.; Shenderovich, M.; Baichwal, V.; Bartel, P.; Cimbora, D.; McKinnon, R.; et al. Discovery of (2S)-1-[4-(2-\{6-amino-8-[(6-bromo-1,3-benzodioxol-5-yl) sulfanyl]-9h-purin-9-yl\}et hyl)piperidin-1-yl]-2-hydroxypropan-1-one (MPC-3100), a purine-based hsp90 inhibitor. J. Med. Chem. 2012, 55, 7480-7501. [CrossRef] [PubMed]

211. Lee, F.A.; Zee, B.C.; Cheung, F.Y.; Kwong, P.; Chiang, C.L.; Leung, K.C.; Siu, S.W.; Lee, C.; Lai, M.; Kwok, C.; et al. Randomized phase II study of the X-linked inhibitor of apoptosis (XIAP) antisense AEG35156 in combination with sorafenib in patients with advanced hepatocellular carcinoma (HCC). Am. J. Clin. Oncol. 2014. [CrossRef] [PubMed]

212. Sessa, C.; Shapiro, G.I.; Bhalla, K.N.; Britten, C.; Jacks, K.S.; Mita, M.; Papadimitrakopoulou, V.; Pluard, T.; Samuel, T.A.; Akimov, M.; et al. First-in-human phase I dose-escalation study of the hsp90 inhibitor auy922 in patients with advanced solid tumors. Clin. Cancer Res. 2013, 19, 3671-3680. [CrossRef] [PubMed]

213. Nikolovska-Coleska, Z.; Xu, L.; Hu, Z.; Tomita, Y.; Li, P.; Roller, P.P.; Wang, R.; Fang, X.; Guo, R.; Zhang, M.; et al. Discovery of embelin as a cell-permeable, small-molecular weight inhibitor of XIAP through structure-based computational screening of a traditional herbal medicine three-dimensional structure database. J. Med. Chem. 2004, 47, 2430-2440. [CrossRef] [PubMed]

214. Pacey, S.; Wilson, R.H.; Walton, M.; Eatock, M.M.; Hardcastle, A.; Zetterlund, A.; Arkenau, H.T.; Moreno-Farre, J.; Banerji, U.; Roels, B.; et al. A phase I study of the heat shock protein 90 inhibitor alvespimycin (17-DMAG) given intravenously to patients with advanced solid tumors. Clin. Cancer Res. 2011, 17, 1561-1570. [CrossRef] [PubMed]

215. Reddy, N.; Voorhees, P.M.; Houk, B.E.; Brega, N.; Hinson, J.M., Jr.; Jillela, A. Phase I trial of the hsp90 inhibitor PF-04929113 (SNX5422) in adult patients with recurrent, refractory hematologic malignancies. Clin. Lymphoma Myeloma Leuk. 2013, 13, 385-391. [CrossRef] [PubMed]

216. Flygare, J.A.; Beresini, M.; Budha, N.; Chan, H.; Chan, I.T.; Cheeti, S.; Cohen, F.; Deshayes, K.; Doerner, K.; Eckhardt, S.G.; et al. Discovery of a potent small-molecule antagonist of inhibitor of apoptosis (IAP) proteins and clinical candidate for the treatment of cancer (GDC-0152). J. Med. Chem. 2012, 55, 4101-4113. [CrossRef] [PubMed]

217. Dickson, M.A.; Okuno, S.H.; Keohan, M.L.; Maki, R.G.; D’Adamo, D.R.; Akhurst, T.J.; Antonescu, C.R.; Schwartz, G.K. Phase II study of the hsp90-inhibitor BIIB021 in gastrointestinal stromal tumors. Ann. Oncol. 2013, 24, 252-257. [CrossRef] [PubMed]

218. Pacey, S.; Gore, M.; Chao, D.; Banerji, U.; Larkin, J.; Sarker, S.; Owen, K.; Asad, Y.; Raynaud, F.; Walton, M.; et al. A phase II trial of 17-allylamino, 17-demethoxygeldanamycin (17-AAG, tanespimycin) in patients with metastatic melanoma. Investig. New Drugs 2012, 30, 341-349. [CrossRef] [PubMed]

219. Dhuria, S.; Einolf, H.; Mangold, J.; Sen, S.; Gu, H.; Wang, L.; Cameron, S. Time-dependent inhibition and induction of human cytochrome P4503A4/5 by an oral iap antagonist, LCL161, in vitro and in vivo in healthy subjects. J. Clin. Pharmacol. 2013, 53, 642-653. [CrossRef] [PubMed]

220. Jhaveri, K.; Chandarlapaty, S.; Lake, D.; Gilewski, T.; Robson, M.; Goldfarb, S.; Drullinsky, P.; Sugarman, S.; Wasserheit-Leiblich, C.; Fasano, J.; et al. A phase II open-label study of ganetespib, a novel heat shock protein 90 inhibitor for patients with metastatic breast cancer. Clin. Breast Cancer 2014, 14, 154-160. [CrossRef] [PubMed] 
221. Asano, M.; Hashimoto, K.; Saito, B.; Shiokawa, Z.; Sumi, H.; Yabuki, M.; Yoshimatsu, M.; Aoyama, K.; Hamada, T.; Morishita, N.; et al. Design, stereoselective synthesis, and biological evaluation of novel tri-cyclic compounds as inhibitor of apoptosis proteins (IAP) antagonists. Bioorg. Med. Chem. 2013, 21, 5725-5737. [CrossRef] [PubMed]

222. Oh, W.K.; Galsky, M.D.; Stadler, W.M.; Srinivas, S.; Chu, F.; Bubley, G.; Goddard, J.; Dunbar, J.; Ross, R.W. Multicenter phase II trial of the heat shock protein 90 inhibitor, retaspimycin hydrochloride (IPI-504), in patients with castration-resistant prostate cancer. Urology 2011, 78, 626-630. [CrossRef] [PubMed]

223. Abd-Elrahman, I.; Hershko, K.; Neuman, T.; Nachmias, B.; Perlman, R.; Ben-Yehuda, D. The inhibitor of apoptosis protein livin (ML-IAP) plays a dual role in tumorigenicity. Cancer Res. 2009, 69, 5475-5480. [CrossRef] [PubMed]

(C) 2016 by the authors; licensee MDPI, Basel, Switzerland. This article is an open access article distributed under the terms and conditions of the Creative Commons by Attribution (CC-BY) license (http://creativecommons.org/licenses/by/4.0/). 